\title{
THE FRAGMENT, THE HALF, AND THE WHOLE: APPROACHING POTTERY AND FAUNA DEPOSITIONS IN PIT 50 OF PERDIGÕES ENCLOSURE (FIRST HALF OF THE 3RD MILLENNIUM BC)
}

\author{
ANTÓNIO CARLOS VALERA ${ }^{(1)}$, ANA CATARINA BASÍLIO ${ }^{(2)}$, NELSON ALMEIDA $^{(3)}$
}

Abstract:

\begin{abstract}
This paper presents the sequence of depositions inside Pit 50 of Perdigões ditched enclosure, dating from the first half of the $3^{\text {rd }}$ millennium BC, and discusses the patterning that emerges from the detailed analysis of the distribution and levels of integrity of pottery and faunal remains along the infilling sequence. It is argued that these patterns are intentional and incorporate metaphorical meanings. Some interpretative hypothesis are put forward, taking in consideration the global scenario provided by Perdigões enclosure, from which this particular context recursively retrieves and provides significance.
\end{abstract}

keywords: Structured depositions, Pottery depositions, Faunal depositions, Chalcolithic, Perdigões.

Resumo:

\begin{abstract}
O Fragmento, A Metade e O Todo: aproximação às deposições de cerâmica e fauna da Fossa 50 do recinto dos Perdigões (primeira metade do $3^{\circ}$ milénio $\mathrm{AC}$ ).

Este artigo apresenta a sequência de deposições no interior da Fossa 50 do recinto de fossos dos Perdigões, datada da primeira metade do $3^{\circ}$ milénio $\mathrm{AC}$, e discute o padrão que emerge de uma análise detalhada da distribuição e níveis de integralidade da cerâmica e restos faunísticos ao longo da sequência. Algumas hipóteses interpretativas são avançadas, tendo em consideração o cenário global proporcionado pelos Perdigões, do qual este contexto específico recursivamente retira e providencia sentido.
\end{abstract}

Palavras-chave: deposições estruturadas, deposições cerâmicas, deposições faunísticas, Calcolítico, Perdigões

\section{INTRODUCTION}

In the overall complexity and richness of a site like Perdigões Neolithic and Chalcolithic ditched enclosure (LAGo et al. 1998; MÁrQUEZ ROMERO et al. 2011a; VALERA 2015; 2017; 2018; VALERA et al. 2014a), to focus in a single pit could look like an excessive attention to detail. The unique, though, is just one particular way of expressing the total (SANTOS 1999). So, the focus in a specific "hole", inserted in the "sea of holes" that is Perdigões, is justified by the relations that can be established between this unit of deposition and the social practices that characterize the site as a whole and the social trajectories of the period. As Johnson put it, "the search for agency seems best to be conducted using small-scale studies as representative of wider changes, in both a temporal and spatial sense" (1989: 206), but that requires the use of actual case studies (DOBRES \& RoBB 2000: 4).

Amongst those practices are the structured or selected depositions and the practices of intentional fragmentation. These practices have been intensively discussed and theorized, and their conceptu- alization proposed as an heuristic tool capable of supporting new interpretative approaches to archaeological contexts, where these practices acquire social meaning (RICHARDS \& THOMAS 1984; BRÜCK 1999; 2006; JORGE et al. 1998-99; CHAPMAN 2000; CHAPMAN \& GAYDARSKa 2007; TÂRLEA 2008; MCFADYEN 2006; GARROW 2012; HARRELL \& DRIESSEN 2015; VAlERA 2010; 2019a - for a recent discussion in Portuguese archaeology see the papers in VALERA 2019a). They involve the choice of the objects, specific forms of manipulation reflected in higher or lower degree of integrity, the times of deposition, the architectonic structuration of the contexts of deposition and other more intangible elements, such as the choreographies (VALERA 2019a) involving the fragmentation and the deposition (gestures, clothing, sounds, aromas, sequences of procedures, participants, assistance, etc.).

The social potential of fragmentation, highlighted by Chapman and Gaydarska (CHAMPAN 2000; Chapman \& GAYDARSKa 2007), rests in part in the psychological relation between part and whole (Fowler 2004; VALERA 2010; 2019a). By

\footnotetext{
${ }^{(1)}$ Era Arqueologia / ICArEHB - Universidade do Algarve. Correspondent author - antoniovalera@era-arqueologia.p

(2) ICArEHB - Universidade do Algarve

${ }^{(3)}$ UNIARQ - Centro de Arqueologia da Universidade de Lisboa
} 
establishing an ontological parity between the part (the fragment) and the whole (the complete object), it is possible, both in terms of representation and of sharing of essences, to generate links between persons, places, objects and moments. This discloses more complex biographies of these contexts, that are also organized text of metaphorical or mnemonic meaning (TiLley 1991), not always easy to identify and even more difficult to decode. Certain detectable patterns, though, may emerge from detailed analysis of an element or assemblages of elements, such as the spatial distribution and its relation to the structure (container of the deposition), the contextual relations between categories of objects, orientation, integrity / levels of fragmentation or presences / absences. That is the case of the depositions inside Pit 50 of Perdigões enclosure, which does not just talk about a set of practices prior to the performances of depositing, but also seem to incorporate statements in the ways they were organised.

\section{PIT 50 OF PERDIGÕES: THE FEA- TURE AND THE INFILLING SEQUENCE}

Pit 50 is in Sector O of Perdigões enclosure, integrating an assemblage of pits $3 \mathrm{~m}$ in front (by the outside) of the western gate of Ditch 10 (Fig. 1: B). This section of the ditch runs in the western middle slope of the natural theatre where the site is located. The gateway is aligned at $270^{\circ}$, that is, to the equinoxes at sunset. In front of it, about $30 \mathrm{~m}$ west, there is the western double gate of Ditches 1 and 2 that run in the top of the slope and that, according to available absolute chronology, are later than Ditch 10. This double gate creates an axis aligned at $280^{\circ} \mathrm{W}-180^{\circ} \mathrm{E}$ with the gate in Ditch 10 (Fig. 1).

The pit has a circular plan, with a trapezoidal section strangled near the top. It is $1,20 \mathrm{~m}$ deep and has a diameter of $1,42 \mathrm{~m}$ in the mouth and $1,62 \mathrm{~m}$ in the base (Fig. 2). It is associated with two small and shallow pits, one at each side (Pits 51 and $52-$ Fig. 1: B).

Its infilling started with the formation of a layer [SU56] containing a central concentration of fauna remains with three parts of an Ovis/Capra spinal column maintaining several lumbar and cervical vertebrae in anatomic connection (Fig.3: H; Fig. 4), and more than a hundred of small pottery fragments (manly rims) and two loom weight fragments. This first layer was covered by another one [SU55], containing dispersed fauna bones, the same number of small pottery fragments and a fragment of loom weight, ending what was considered the Phase 1 of infilling.

Phase 2 started with the construction of a semicircle of stones over the previous layer, attached to the North wall of the pit (Fig. 3: G), and with the formation of internal [SU54] and external [SU52] deposits, again containing some dispersed pottery sherds and faunal remains. In [SU52] were deposited two posterior appendicular extremities of a juvenile Capra hircus, one right and one left,
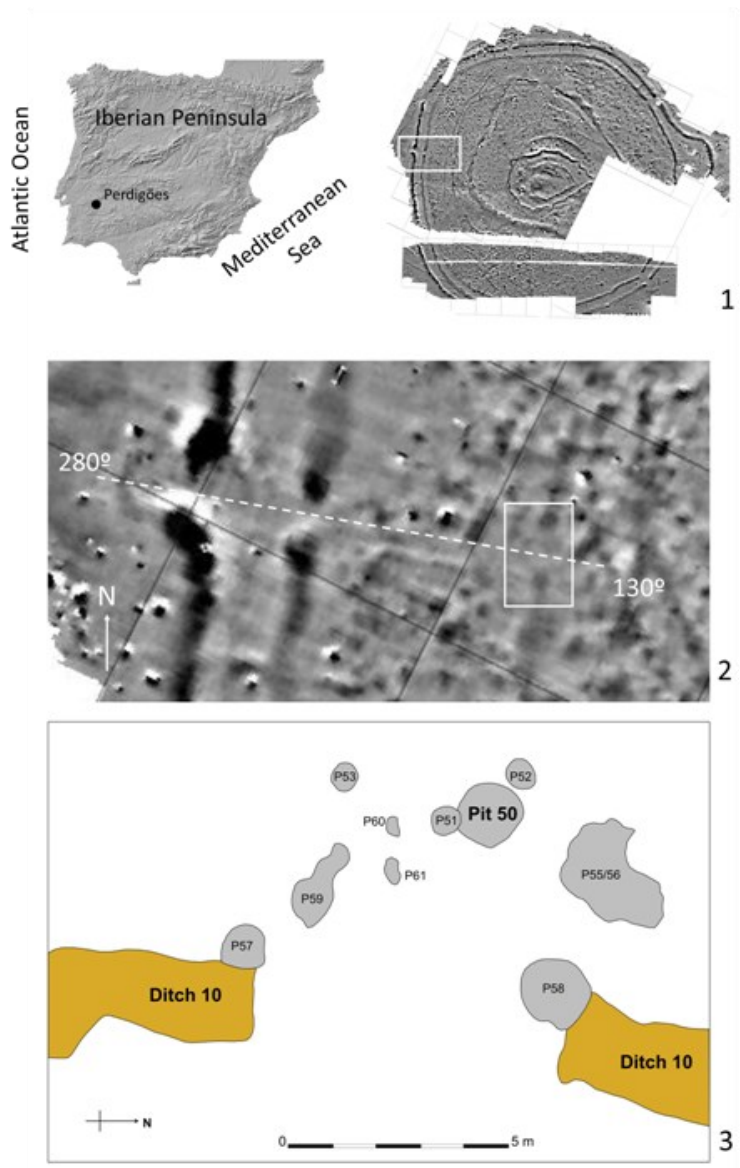

Fig. 1: 1 - Location of Perdigões in Iberia and of the analysed area in Perdigões magnetogram; 2 - Detail of the analysed area in the magnetogram, with the gates of Ditch 10 and of Ditches 1 and 2; 3 - Location of Pit 50 in front of the gate in Ditch 10 .

with metatarsals and phalanges in connection. Then, over the stone semicircle and [SU54] an intense deposition of fauna remains [SU51] occurs, containing several parts of anterior and posterior limbs of at least one juvenile and one adult Capra hircus in anatomical connection (Fig. 3: F; Fig. 5) and a smaller number of materials. This concentration was covered by a deposit [SU50] that presents the higher number of dispersed pottery sherds of all stratigraphy.

After that, the characteristics of the infilling changed again (Phase 3). A deposit integrating a large slab of schist and several gabbro stones is formed [SU45]. In the middle of the stones was deposited a mandible of Bos sp. with all its teeth missing (only one upper first molar of Bos taurus was recovered in the pit [SU50]) (Fig. 3: D) and in the top of the stones is placed a section of a Sus sp. cranium, corresponding to an old individual. This is covered by a sequence of clayish deposits and an agglomeration of stones [SUs46, 44, 33, 32, 31, $30]$, with progressively lower numbers of pottery sherds and faunal remains, that are residual or inexistent in the latest levels [SU31, 30]. In this phase, the pit is filled up to the level of the strangled section. 
In Phase 4, integrating the layer [SU28], three halves of three different pots (a plate and two bowls) were deposited (Fig. 3: C; Fig. 6 and 7). The halves of the bowls were deposited complete, but the plate's half was deposited broken or broken in place, for some fragments were turned back (Fig. 6). Apart from these three halves, only one sherd of a rim was recorded in this moment of deposition.
After that (Phase 5), over SU28, a complete bowl was deposited over a "bed" of small stones (Fig. 3: B; Fig. 6 and 7). The bowl was then involved by two deposits [SU22, SU10] that completed the filling of the pit that was levelled by the top of the complete pot (Fig. 3: A). These deposits integrate some small pottery sherds, few small fragments of fauna and a schematic anthropomorphic figurine made of clay.

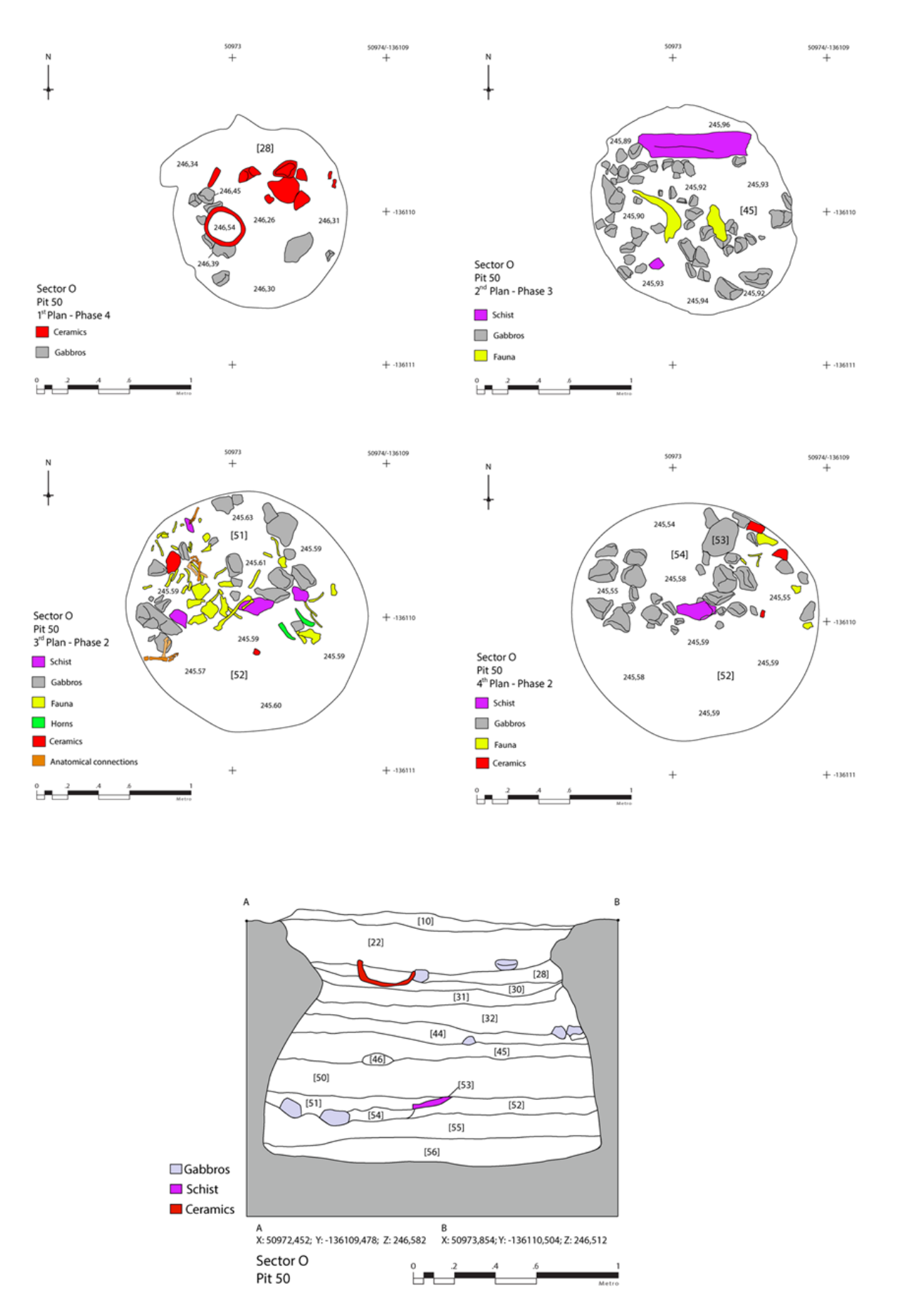

Fig. 2: Plans and section of Pit 50 

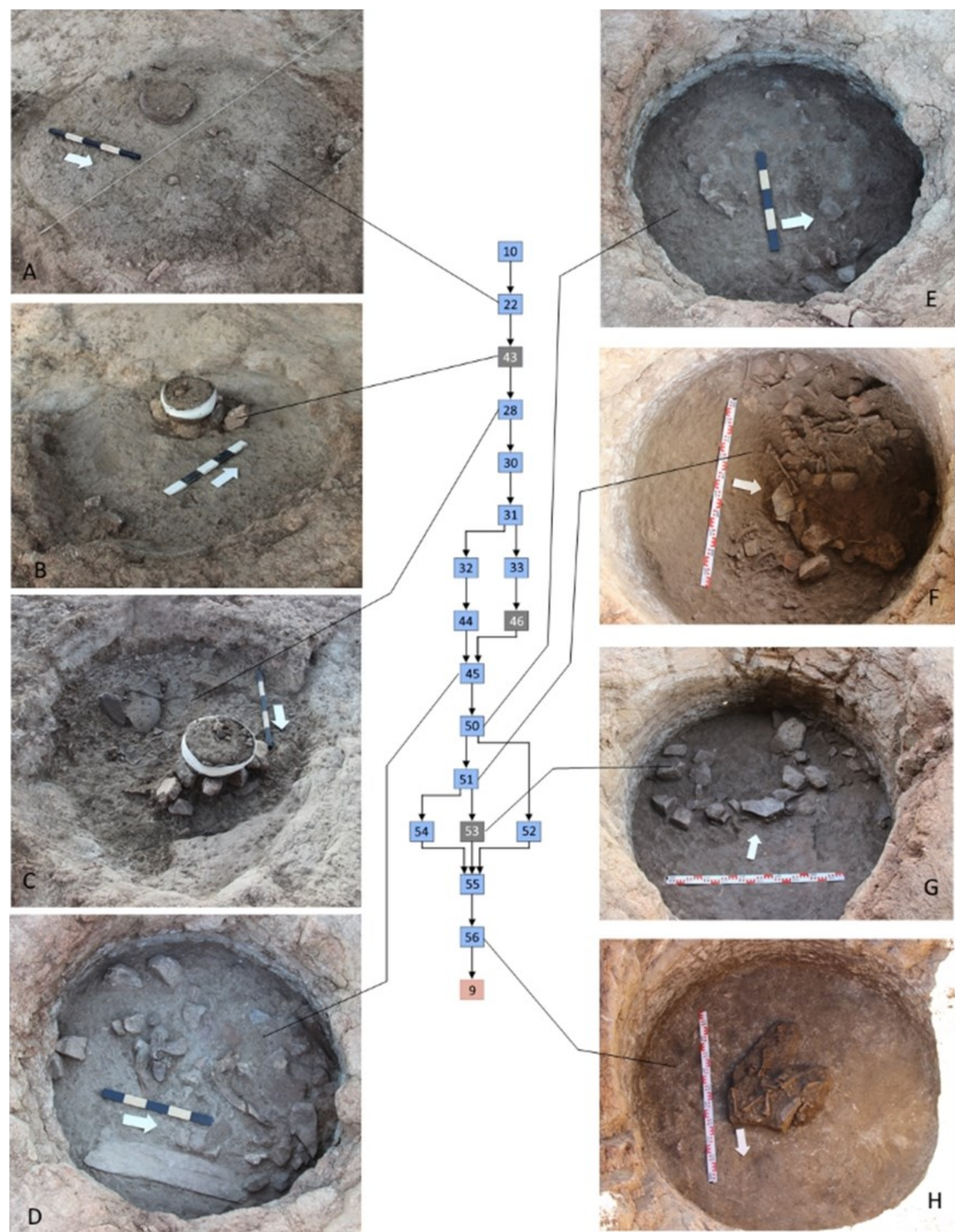

Fig. 3: Sequence of infillings of Pit 50. 
The Fragment, The Half, and The Whole: approaching pottery and fauna depositions in Pit 50 of Perdigões enclosure (first half of the $3 r d$ millennium $B C$
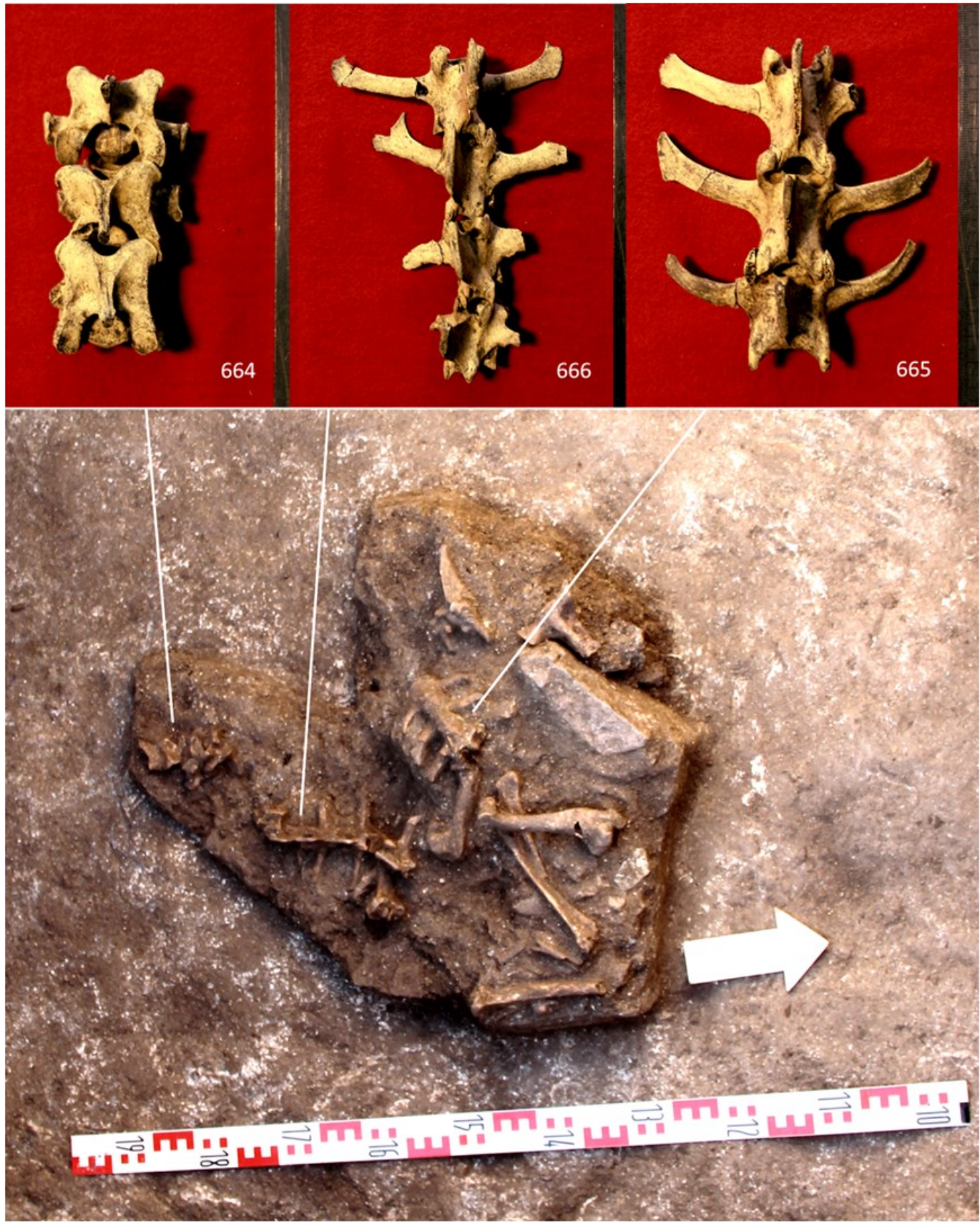

Fig. 4: Parts of an Ovis/Capra spinal column maintaining several lumbar and cervical vertebrae in anatomic connection in the bottom of the pit. 


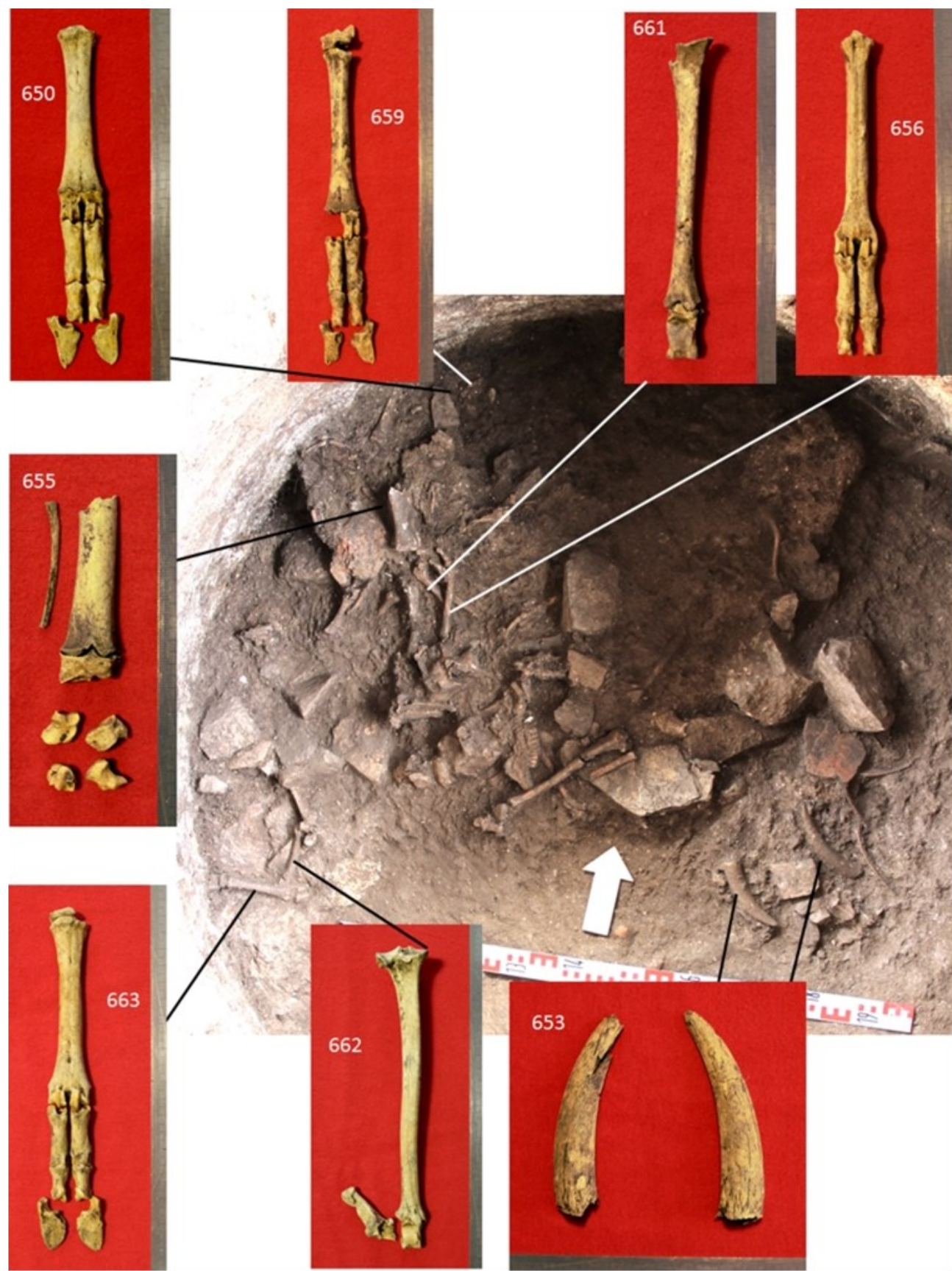

Fig. 5: Intense deposition of fauna remains in [SU51], containing several parts of anterior and posterior limbs and a pair of horns of at least one juvenile and one adult Capra hircus. 


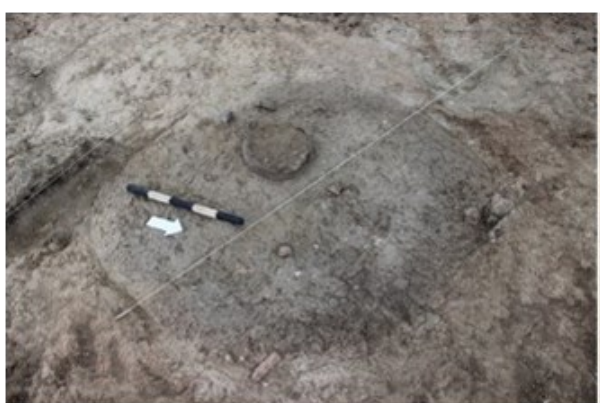

1
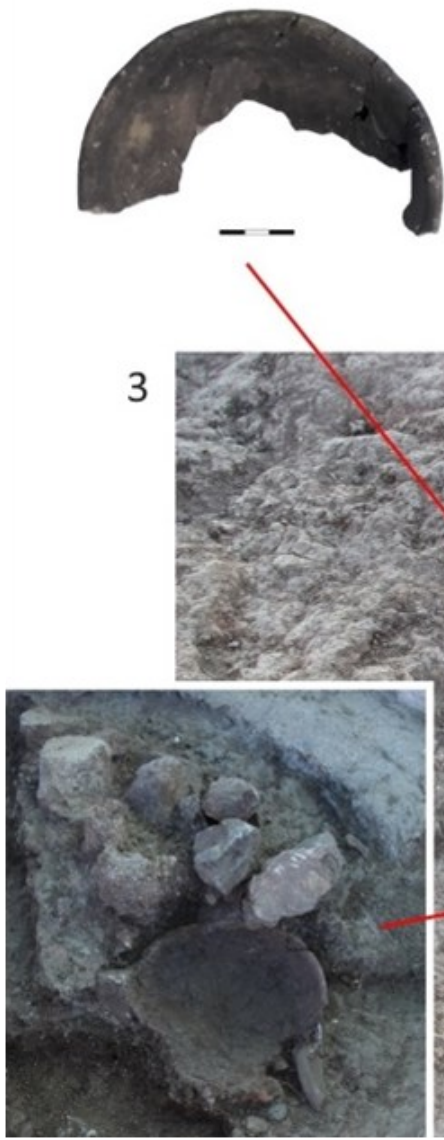

Fig. 6: Depositions of halves and of a complete pot over a "pedestal" of stones. 1- Top of the complete pot emerging in the infilling; 2 - Complete pot over the stone "pedestal"; 3 - Half fragments in the deposit below the complete pot.

\section{MATERIALS IN THE STRATIGRAPHIC SEQUENCE}

The artefactual assemblage recovered in Pit 50 presents 1267 identified elements (Table 1). Of this total, $97 \%$ correspond to ceramic elements, with a weight that exceeds $26 \mathrm{~kg}$. As such, the remaining materials are scarce.

In the 1285 pottery elements there is a predominance of the body parts $(84 \%$ of the total of the ceramic set), with a weight approaching $17 \mathrm{~kg}$. The remaining 198 elements (with 9506 gr) correspond mainly to rim sherds, but a complete con-

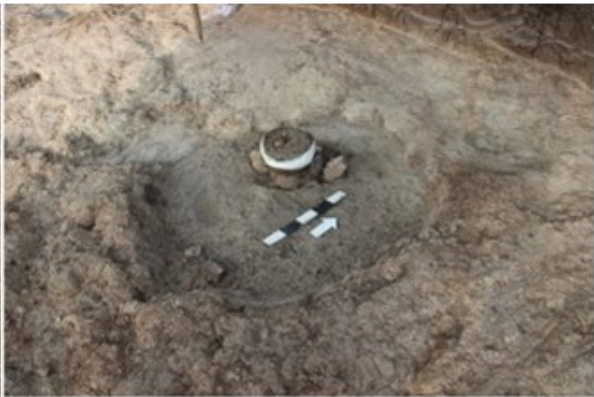

2
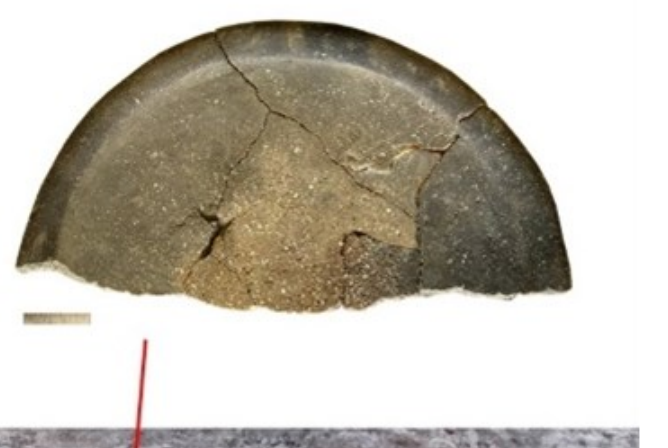
Table 1: Archaeological materials deposited inside pit 50.

\begin{tabular}{|c|c|c|c|c|c|c|c|c|c|c|}
\hline Phase & S.U. & Rims & $\begin{array}{l}\text { Shoulders/ } \\
\text { Nipples }\end{array}$ & $\begin{array}{l}\text { Vessels/ } \\
\text { halfs }\end{array}$ & $\begin{array}{l}\text { Body } \\
\text { parts }\end{array}$ & $\begin{array}{l}\text { Loom } \\
\text { weights }\end{array}$ & Lithics & Metal & Ideotechnique & Total \\
\hline \multirow{2}{*}{5} & 10 & 2 & 0 & 0 & 52 & 2 & 3 & 0 & 1 & 60 \\
\hline & 22 & 20 & 0 & 1 & 60 & 1 & 1 & 0 & 0 & 83 \\
\hline 4 & 28 & 1 & 0 & 3 & 0 & 0 & 0 & 0 & 0 & 4 \\
\hline \multirow{5}{*}{3} & 30 & 6 & 0 & 0 & 0 & 0 & 0 & 0 & 0 & 6 \\
\hline & 31 & 0 & 0 & 0 & 0 & 0 & 0 & 0 & 0 & 0 \\
\hline & $32 / 33$ & 12 & 0 & 0 & 75 & 3 & 11 & 0 & 0 & 101 \\
\hline & 44 & 9 & 0 & 0 & 51 & 1 & 0 & 0 & 0 & 61 \\
\hline & 45 & 7 & 2 & 0 & 79 & 2 & 1 & 0 & 0 & 91 \\
\hline \multirow{3}{*}{2} & 50 & 53 & 5 & 0 & 373 & 8 & 10 & 2 & 1 & 452 \\
\hline & 51 & 12 & 0 & 0 & 32 & 0 & 1 & 0 & 0 & 45 \\
\hline & $52 / 54$ & 3 & 0 & 0 & 102 & 0 & 5 & 0 & 0 & 110 \\
\hline \multirow{2}{*}{1} & 55 & 23 & 2 & 0 & 112 & 1 & 0 & 0 & 0 & 138 \\
\hline & 56 & 17 & 0 & 0 & 115 & 2 & 0 & 0 & 0 & 134 \\
\hline Total & & 165 & 9 & 4 & 1051 & 20 & 32 & 2 & 2 & 1285 \\
\hline
\end{tabular}

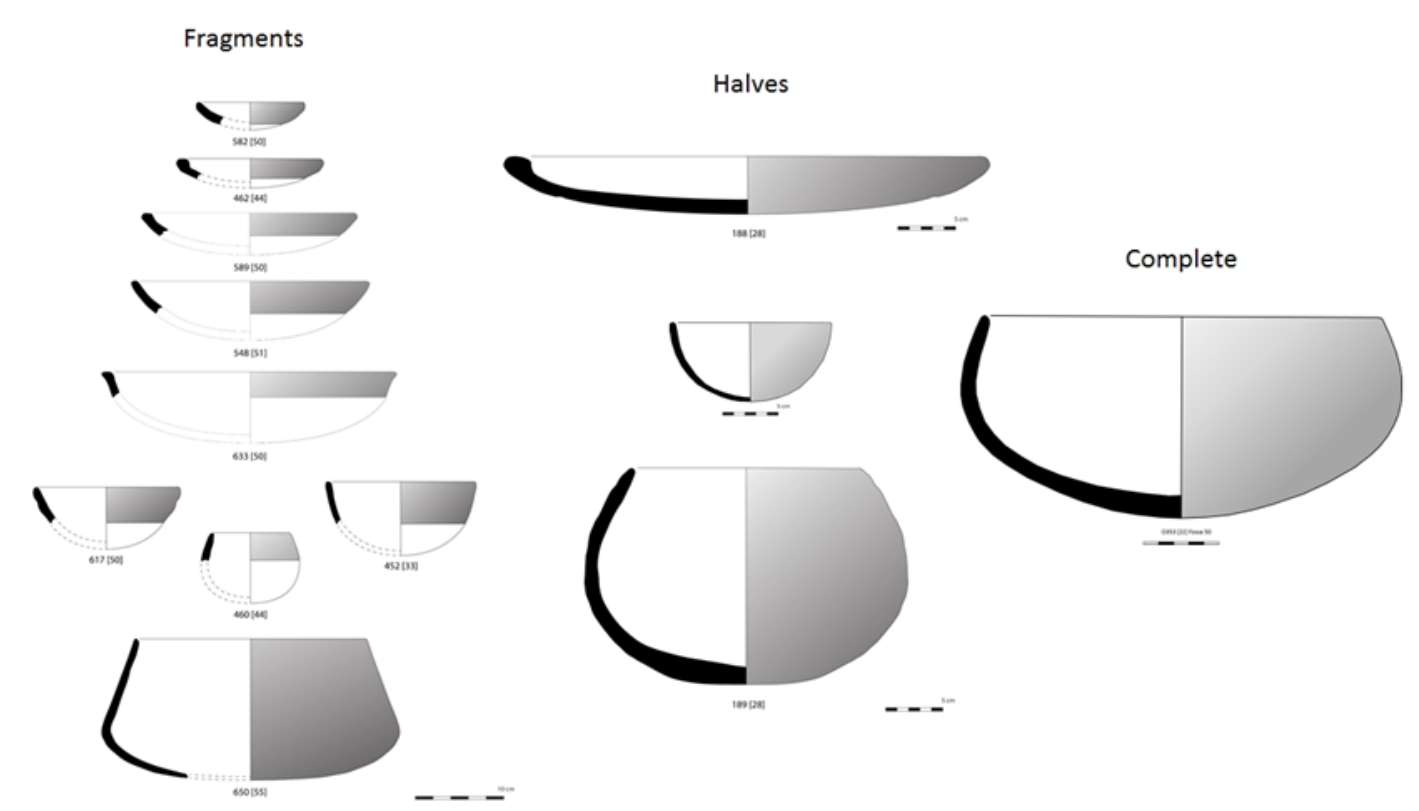

Fig. 7: Pottery shapes from Pit 50.

are concentrated in the first three size classes, with emphasis on the 3rd group (Fig. 8). This feature was also confirmed in the body parts, whose degree of fragmentation, which in this case comes from the relation between weight/quantity, show that, on average, each fragment would have 16 grams (between the weight defined for classes 2 and 3 ).

This degree of fragmentation is extremely high, with just one refitting between sherds (two rims, one from SU55 and another one from SU50, which stratigraphically do not present a direct physical relation), showing that pottery inside the pit is represented mainly by small fragments from different pots. The exceptions are the already referred 3 halves and a complete vessels deposited in the top layers of the infilling.
This fragmentation range made impossible the morphological determination of 85 rim sherds. Still, in most of the assemblage, typical forms of the 3rd millennium BC in the South of Portugal were recognized, with a clear predominance of plates (29 elements), in their bi-thickened variant (13 fragments). The bowls and deeper bowls (18 records each) also stand out in the total set, being verified a preference for the simpler forms. In addition to these, simple spherical containers (14 fragments), globular vessels (eight elements), and a low shoulder container were also identified (Fig.7). The loom weight fragments, in a total of 20 , corroborate the general chronological characteristics of the set, denoting a predominance of the crescent type $(65 \%)$.

As to the distribution of these elements 


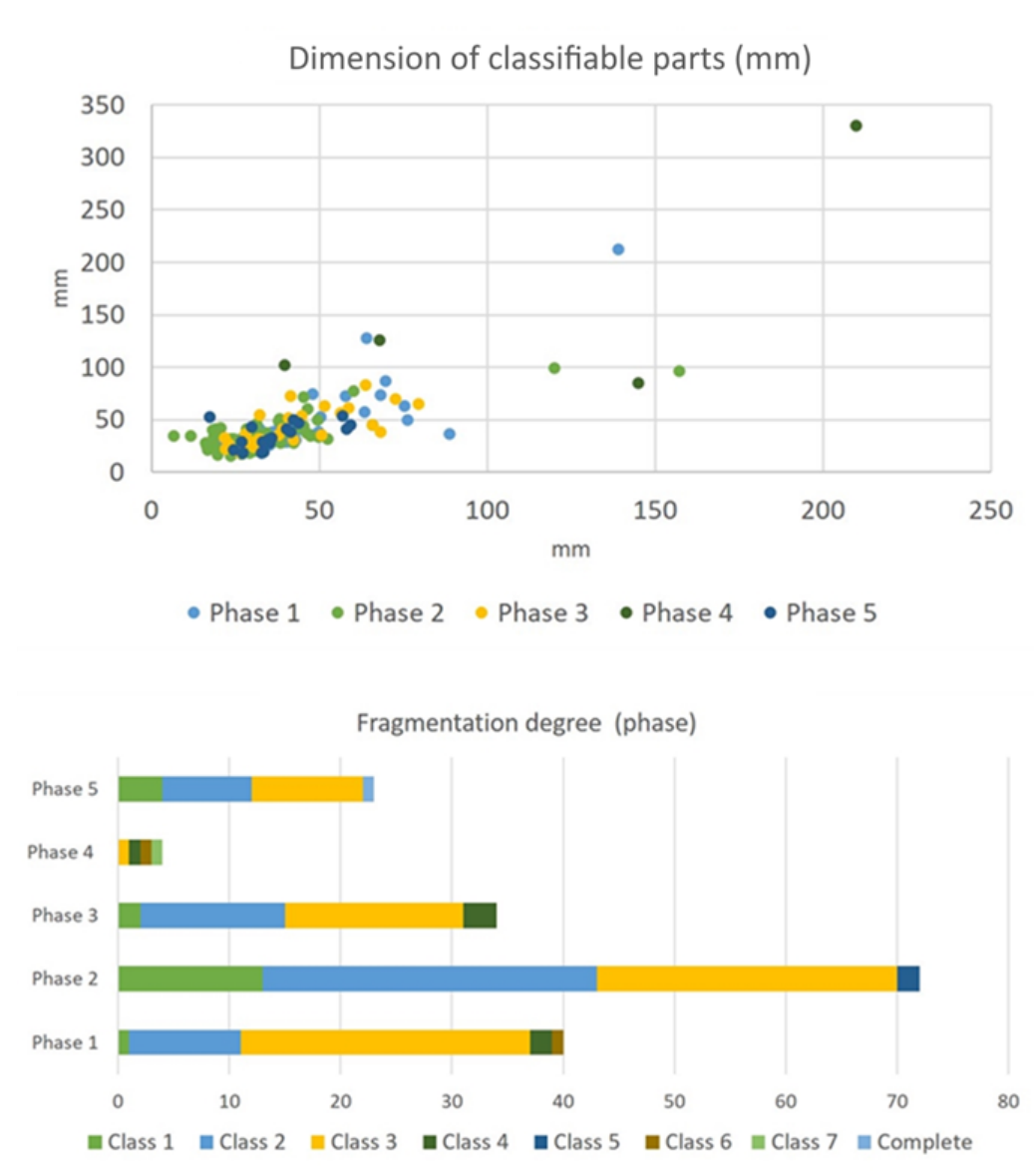

Fig. 8: Degree of fragmentation of pottery and its distribution by phase in the sequence of infilling.

(classifiable and body parts) by the various stratigraphic units within the pit, there is a clear concentration in the lower half of the structure, starting from [SU30]. However, the major concentration is in [SU50], with $35 \%$ of the entire artefactual set (Fig.8 and 9).

The lithic materials, as it happens in many of the contexts already analysed in Perdigões, have a low representativeness, not surpassing the 32 elements. Nevertheless, these pieces are distributed in several categories, such as three pebbles and five pebble fragments, two broken arrowheads and four knapping tools, denoting the preference for an "occasional"/expedite productive technology (LAGO et al. 1998).

In the line with what was identified in the ceramic elements, the lithics also present a distinct distribution along the stratigraphy, being $69 \%$ of these artefacts distributed between [SU32/33] and [SU50] (Fig. 9).

In terms of the raw materials, there is a great diversity, even though the quartz clearly stands out, used in 17 artefacts. Other 11 lithic elements were made out of quartzite, flint and jasper.

Besides the pottery, loom weights and lithic elements, which together account for $99.69 \%$ of the total material of Pit 50, evidence of the transformation and metallurgical handling in the form of castings and a possible fragment of copper ore have also been identified. Furthermore, a possible ceramic "horned idol" [SU50], which classification was not facilitated considering the level of fragmentation, and an anthropomorphic schematic figure [SU10] were also collected in the pit.

In general, the assemblage is relatively homogeneous and cohesive at a chronological level, relying on typical elements of the 3rd millennium $\mathrm{BC}$ in Alentejo. However, the different distribution of the artefacts along the stratigraphic units is clear, with a greater concentration and degree of fragmentation in the lower part of the structure, as opposed to the higher part (Fig. 9).

In the first infilling stage, Phase 1, only ceramic elements were identified (42 rims and 227 body parts) without the presence of any other type of artefact. At the formal level, as verified in the general analysis, the plates stand out, with nine individualized elements, of which seven with a bithickened rim. The relevance of the spherical and globular vessels, with four elements each, is also noted, with preference being given to their simpler variants. It is at this stage that the larger fragment of a low shoulder container is recorded, as well as the presence of two residual fragments of shoulders ( 15 sherds have an undetermined shape). In terms of fragmentation, most of the sherds are distributed between classes 2 (ten elements) and 3 (26 elements), following the general trend of the set, 
which is reinforced by the average weight by fragment around $20.33 \mathrm{~g}$, a value closer to the ones associated to class 3 . However, it was possible to distinguish between the two moments that integrate Phase 1, with an increase in the presence of frag- ments, both rims and body parts, in [SU55]. No significant changes were observed in the degree of fragmentation, noting only the presence of an element that is part of class 6 (larger low shoulder fragment).

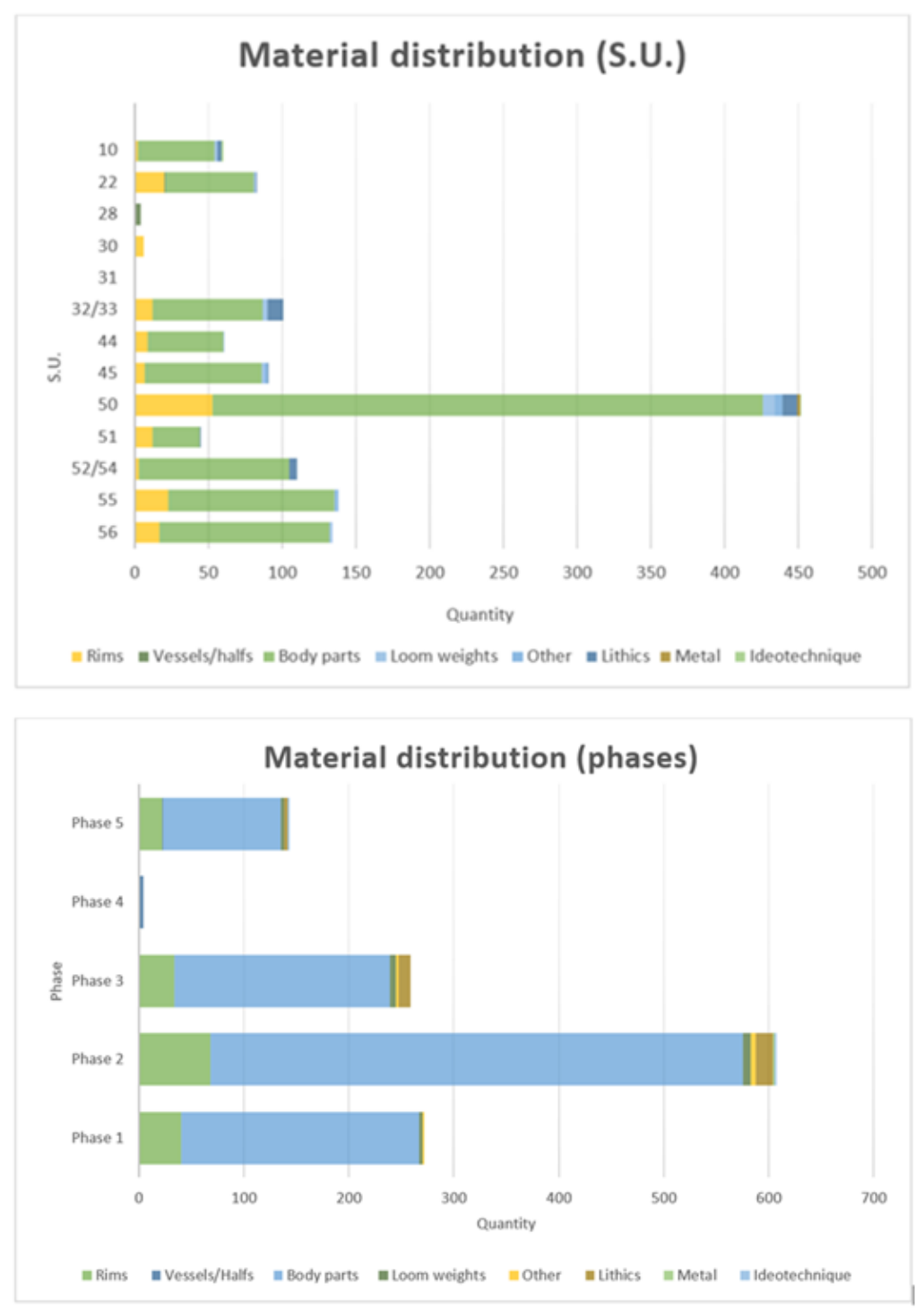

Fig. 9: Artefact distribution by stratigraphic unit and by phase.

Phase 2 has an increase in the variety of materials. Pottery remains are dominant, counting a total of 507 body sherds and 82 classifiable elements. In terms of typology, the trend identified in phase 1 is maintained, with the dominance of the plates, mainly externally thickened, as well as the presence of bowls and spherical vessels. The reduced presence of shoulders and loom weights is noted, although with greater expression than in phase 1.The ceramic is more fragmented than previously, with an increase of class 1 of size and a higher concentration of fragments in class 2. This tendency is also maintained in the body sherds, with a slight decrease in the total weight approach- ing the reference values of class 2. Other materials are now present: pebbles and pebble fragments, two fragments of arrowheads and three knapping tools, the castings, a possible copper ore and a thick, very eroded and rounded ceramic block with a silhouette that bears similarities to the artefacts known as "horn idols".

There is a reduction in the number of artefacts in the first layers of this phase [SU52/54]. This behaviour is maintained in [SU51], where only 45 artefacts were recorded, with an opposite trend regarding the faunal elements, that have a higher number of identifications and several anatomical parts (limbs) in anatomical connection. 
This changes in a later moment of phase 2 , with the formation of [SU50], that concentrates the highest number of archaeological materials in the whole structure (452 elements), again with depositional practice of dispersed small ceramic fragments compatible with classes $2 / 3$ with no refitting.

In Phase 3 the same general ceramic characteristics and fragmentation patterns described in the previous moments is observed, but with a decrease in numbers. The inverse situation is observable in the case of lithics, where there is a greater presence when compared with the previous phase.

The scenario is significantly altered in Phase 4 , with the deposition of the three pottery halves and the almost total absence of small fragments that characterize the previous deposits.

Finally, Phase 5 marks again a moment of depositions of a higher number of archaeological materials, with a total of 143 . The ceramics, also dominant, presents a low rate of typological identification, with only 10 classifiable elements, mostly fragments of bowls and spherical vessels, contrary to the trend of the previous phases, where thickened rim plates are predominant. However, as far as fragmentation is concerned, most of the body and rim sherds of phase 5 have dimensions that match the parameters of class 3 , being the exception the complete bowl deposited over the "pedestal" of stones.

The remaining artefacts are poorly represented, with the existence of three fragments of loom weights of the crescent type and of two quartz fragments, a quartzite pebble core and a quartz cortical splinter and a schematic anthropomorphic figurine (Fig. 10) deposited in the last layer of the pit [SU10], marking the end of the process of the infilling of this structure.

In sum, the analysis of the distribution of materials by phase in the infilling sequence of Pit 50 shows differences in the incorporated material between phases. The divergences between the various moments are essentially materialized in quantitative and qualitative changes, with a small-

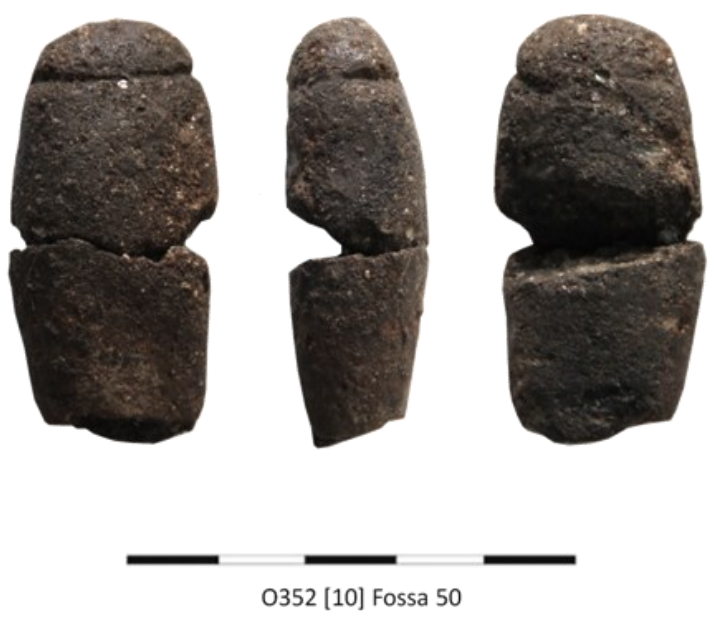

Fig. 10: Schematic clay anthropomorphic figurine. er number of materials and less typological/formal variety, as occurs in phases 1 and 3 , followed by moments of greater concentration and diversity, as it happens in phase 2. These different depositional processes would have occurred rapidly, once there are no signs of erosion on the surfaces of the artefacts and especially in the faunal remains, where weathering is present but with minimal degrees of affectation. Emphasis should also be put in phases 4 and 5, that correspond to moments of change regarding the characteristics of the previous artefactual assemblages, manly related to the presence of the pottery halves identified in phase 4 , and the complete container and the anthropomorphic figurine of phase 5 .

Finally, it is also worth noting that to this high degree of fragmentation corresponds a residual percentage of refitting of fragments of rims, showing that hey represent different vessels almost in total, suggesting some sort of selection.

\section{THE FAUNAL REMAINS}

\subsection{Methodology}

The faunal assemblage was analysed following common methodologies in zooarchaeology and taphonomy (Lyman 1994; ReITZ \& WING 2008) and special attention was given to the differentiation between similar species (e.g., ZEDER \& Lapham 2010; Zeder \& PIlaAR 2010). Biometric data was obtained with a Lux calliper according to DRIESCH (1976) and other authors in specific cases (PAYNE \& BUll 1988; DAVIS 1996; Albarella et al. 2005). Demographic profiles were established based on bone development, tooth eruption and use wear (e.g., Bull \& PAYNE 1982; GRAnt 1982; PAYNe 1987; Zeder 2006; LEMOINE et al. 2014) and grouped according to general classes: infant, juvenile/sub-adult, adult and senile. Remains, even those not identified taxonomically, were tentatively grouped in generic weight groups: very small $(<20 \mathrm{~kg})$, small $(20-100 \mathrm{~kg})$, medium $(100-300 \mathrm{~kg})$ and large size $(>300 \mathrm{~kg})$. Common quantitative units were implemented, namely Number of Identified Specimens (NISP), Minimum Number of Elements (MNE) and Minimum Number of Individuals (MNI) (Lyman 2008).

Fracture analysis followed VILLA \& MAHIEU (1991) concerning delineation, degree and surface of cortical fracture planes. Bone surface modifications such as anthropogenic fractures (e.g., percussion impacts) and cut marks (e.g., incisions), tooth marks (e.g., pits) and presence of thermoalterations, among others (LyMAN 1994), were recorded by means of a binocular loupe and described according to their position, morphology and intensity. Cut marks and tooth marks maximum dimensions were obtained with a digital Lux calliper or combining a digital microscope DigiMicro 2.0 Scale and MicroCapture $\odot$. Other indicators, such as weathering (BEHRENSMEYER 1978), trampling and precipitation of oxides, among oth- 
ers, were quantitatively and qualitatively recorded (Almeida 2017).

\subsection{Results}

The vertebrate fauna assemblage from Pit 50 corresponds to 724 remains of which $643(88,8 \%)$ are bone fragments and $52(7,2 \%)$ loose teeth, while bone + tooth $(15,2,1 \%)$ or horns $(14,1,9 \%)$ have lower abundances. A total of $265(36,6 \%)$ remains were taxonomically identified to some degree with the remaining corresponding essentially to undetermined (n 178) or small sized weight group remains (n 210). Anatomic identification was achieved in $462(63,8 \%)$ records, while 89 $(12,3 \%)$ were classified as long bones, $95(13,1 \%)$ as flat bones and $78(10,8 \%)$ considered undetermined.

The dispersion of remains among the phases of infilling of pit 50 indicates that almost half of the records are from Phase 2, especially [SU51] that corresponds to $32,1 \%$ of the assemblage. It is clear that after an initial moment where faunal remains are well represented (Phase 1) there is a strong increase in their number in Phase 2 that is followed by a decrease in Phase 3. After an important diminishing in the quantity of remains during Phase 4 they become vestigial in Phase 5 (Table 2). In fact, within Phase 2 there are some differences as well, with lower units [SU54 and 52] having comparatively much less remains than [SU51 and SU50] or even in comparison to both Phase 1 [SU55 and SU56].

The taxa identified comprise Bos, Cervus elaphus, Caprines, Sus and other smaller size vertebrates (Tables 3, 4, 5 and 6). The most abundant species is Capra hircus, represented by several elements from the cranial, axial and appendicular skeleton, including appendicular extremities in anatomical connection, besides other scattered remains. Ovis aries is vestigial and we must take into account the important representativeness of Ovis/Capra remains from different anatomic regions.

Sus is well represented in the assemblage and some remains were identifiable as Sus domesticus do to their biometrics, still the majority were considered Sus sp..Comparatively scarcer, Bos are present in the assemblage. Both cranial and appendicular elements but mainly limb extremities represent Bos sp.. A second phalange and a proximal femur portion allowed for the identification of Cervus elaphus in the assemblage. Among leporids, Oryctolagus cuniculus is more abundant with elements of the cranial, axial and appendicular skeleton.

Concerning the distribution of species and their representativeness according to the different phases of infilling, some interesting aspects are evident. During Phase 1 there is a good representation of Bos remains, mainly in [SU55] with 4 out of 6 remains present, corresponding to Bos taurus ( 1 astragalus, 1 phalange) and Bos sp. ( 3 pelvis fragments, 1 distal radius). A proximal femur from
Table 2 - Number of identified specimens (NISP and \% NISP) per Phase and Stratigraphic Unit.

\begin{tabular}{lcccc}
\hline SUs & NISP & NISP\% & Phase & $\begin{array}{c}\text { NISP\% / } \\
\text { phase }\end{array}$ \\
\hline SU 22 & 3 & 0,4 & 5 & 0,4 \\
\hline SU 28 & 45 & 6,2 & 4 & 6,2 \\
\hline SU 30 & 10 & 1,4 & & \\
SU 31 & 35 & 4,8 & & \\
SU 33 & 32 & 4,4 & 3 & 18,9 \\
SU 44 & 16 & 2,2 & & \\
SU 45 & 44 & 6,1 & & \\
\hline SU 50 & 82 & 11,3 & & \\
SU 51 & 233 & 32,2 & & \\
SU 52 & 28 & 3,9 & 2 & 25,4 \\
SU 54 & 12 & 1,7 & & 100 \\
\hline SU 55 & 98 & 13,5 & & \\
SU 56 & 86 & 11,9 & & \\
\hline Total & 724 & 100 & & \\
\hline & & & & \\
\hline
\end{tabular}

a sub-adult Cervus elaphus was also identified. Capra hircus and cf. Capra hircus cranial, axial and appendicular elements are well represented but Ovis/Capra is the most abundant group with vertebrae, metapodials, phalanges, long bones and 2 pelvis fragments. A left mandible from [SU55] indicates the presence of an infant cf. Capra hircus with less than6 months. Cranial (including loose teeth) and appendicular elements were also recovered. Elements found in connection seem to all correspond to Capra hircus but 2 Ovis aries calcaneus and 1 horn were identified. Comparatively less abundant, Sus is represented by cranial (including maxilla) and appendicular (scapulae, humerus, phalange) bones from 1 infant and $1 \mathrm{se}-$ nile individual.

Bovid remains are still present in [SU50, 51 and 54] that correspond to Phase 2. One crochu and 2 unfused metapodial condyles represent Bos sp.; 1 loose upper first molar $\left(\mathrm{M}^{1}\right)$, a fusing proximal tibia and 4 phalanges were identified as Bos taurus. The only Cervus elaphus record identified (second phalange) in this phase corresponds to [SU50]. Capra hircus is represented by distal appendicular elements, some of them in anatomical connection, including carpals/tarsals, metapodials, and phalanges. Besides 1 Ovis aries phalange, pelvis fragments of an infant Ovis/Capra and other elements from the appendicular and cranial skeleton were recorded. Sus is represented by loose teeth and appendicular bones, some of which identifiable as Sus domesticus, including a mandible. The majority of Leporidae and Oryctolagus cuniculus remains are from [SU51] and correspond to cranial, axial and appendicular bones. Among taxonomically unidentified remains, ribs, vertebrae, and other axial and cranial fragments were recorded.

With Phase 3 the number of faunal remains starts to decrease. Only one Bos sp. mandible was 
The Fragment, The Half, and The Whole: approaching pottery and fauna depositions in Pit 50 of Perdigões enclosure (first half of the $3 r d$ millennium $B C$

Table 3 - Main quantification indexes calculated for the fauna assemblage of Pit 50.NISP = Number of identified specimens; $\mathrm{MNE}=$ Minimum number of elements; $\mathrm{MNI}=$ Minimum number of individuals.

\begin{tabular}{|c|c|c|c|c|c|c|}
\hline Taxa & NISP & $\% \mathrm{NISP}$ & MNE & $\% \mathrm{MNE}$ & MNI & $\% \mathrm{MNI}$ \\
\hline Bos taurus & 8 & 1,1 & 8 & 4,0 & 3 & 15,8 \\
\hline Bos sp. & 8 & 1,1 & 6 & 3,0 & 0 & 0,0 \\
\hline Capra hircus & 75 & 10,4 & 70 & 35,4 & 4 & 21,1 \\
\hline cf. Capra hircus & 19 & 2,6 & 14 & 7,1 & 0 & 0,0 \\
\hline Ovis aries & 4 & 0,6 & 4 & 2,0 & 1 & 5,3 \\
\hline Ovis/Capra & 78 & 10,8 & 46 & 23,2 & 1 & 5,3 \\
\hline Cervus elaphus & 2 & 0,3 & 2 & 1,0 & 1 & 5,3 \\
\hline Sus domesticus & 9 & 1,2 & 8 & 4,0 & 2 & 10,5 \\
\hline Sus sp. & 45 & 6,2 & 24 & 12,1 & 2 & 10,5 \\
\hline Vulpes vulpes & 1 & 0,1 & 1 & 0,5 & 1 & 5,3 \\
\hline Lepus sp. & 1 & 0,1 & 1 & 0,5 & 1 & 5,3 \\
\hline O. cuniculus & 11 & 1,5 & 11 & 5,6 & 2 & 10,5 \\
\hline Leporidae & 3 & 0,4 & 2 & 1,0 & 0 & 0,0 \\
\hline Aves ind. & 1 & 0,1 & 1 & 0,5 & 1 & 5,3 \\
\hline \multicolumn{7}{|l|}{ Weight group } \\
\hline Very small & 6 & 1,3 & & & & \\
\hline Very small/small & 24 & 5,2 & & & & \\
\hline Small & 210 & 45,8 & & & & \\
\hline Small/Medium & 20 & 4,4 & & & & \\
\hline Medium & 1 & 0,2 & & & & \\
\hline Medium/Large & 16 & 3,5 & & & & \\
\hline Medium & 4 & 0,9 & & & & \\
\hline Unidentified & 178 & 64,9 & & & & \\
\hline Total & 724 & 100 & 198 & 100 & & \\
\hline
\end{tabular}

Table 4 - Number of identified specimens (NISP and \%NISP) for the taxa identified in Pit 50 according to the different phases of infilling identified.

\begin{tabular}{|c|c|c|c|c|c|c|c|c|c|c|}
\hline \multirow{2}{*}{ Taxa } & \multicolumn{2}{|c|}{ Phase 1} & \multicolumn{2}{|c|}{ Phase 2} & \multicolumn{2}{|c|}{ Phase 3} & \multicolumn{2}{|c|}{ Phase 4} & \multicolumn{2}{|c|}{ Phase 5} \\
\hline & $\mathbf{n}$ & $\%$ & $\mathbf{n}$ & $\%$ & $\mathbf{n}$ & $\%$ & $\mathbf{n}$ & $\%$ & $\mathbf{n}$ & $\%$ \\
\hline Bos taurus & 2 & 2,1 & 6 & 4,6 & & 0,0 & & 0 & & 0 \\
\hline Bos sp. & 4 & 4,2 & 3 & 2,3 & 1 & 3,1 & & 0 & & 0 \\
\hline Capra hircus & 15 & 15,6 & 54 & 41,2 & 6 & 18,8 & & 0 & & 0 \\
\hline cf. Capra hircus & 9 & 9,4 & 10 & 7,6 & & 0,0 & & 0 & & 0 \\
\hline Ovis aries & 3 & 3,1 & 1 & 0,8 & & 0,0 & & 0 & & 0 \\
\hline Ovis/Capra & 54 & 56,3 & 21 & 16,0 & 3 & 9,4 & & 0 & & 0 \\
\hline Cervus elaphus & 1 & 1,0 & 1 & 0,8 & & 0,0 & & 0 & & 0 \\
\hline Sus domesticus & 1 & 1,0 & 4 & 3,1 & 4 & 12,5 & & 0 & & 0 \\
\hline Sus sp. & 6 & 6,3 & 20 & 15,3 & 16 & 50,0 & 3 & 60 & & 0 \\
\hline Vulpes vulpes & & 0,0 & & 0,0 & & 0,0 & & 0 & 1 & 100 \\
\hline Lepus sp. & 1 & 1,0 & & 0,0 & & 0,0 & & 0 & & 0 \\
\hline O. cuniculus & & 0,0 & 8 & 6,1 & 1 & 3,1 & 2 & 40 & & 0 \\
\hline Leporidae & & 0,0 & 2 & 1,5 & 1 & 3,1 & & 0 & & 0 \\
\hline Aves ind. & & 0,0 & 1 & 0,8 & & 0,0 & & 0 & & 0 \\
\hline Total & 96 & 100 & 131 & 100 & 32 & 100 & 5 & 100 & 1 & 100 \\
\hline
\end{tabular}


Table 5 - Number of identified specimens (NISP) by taxa and anatomic element for the Pit 50 assemblage.

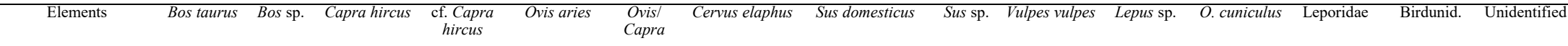

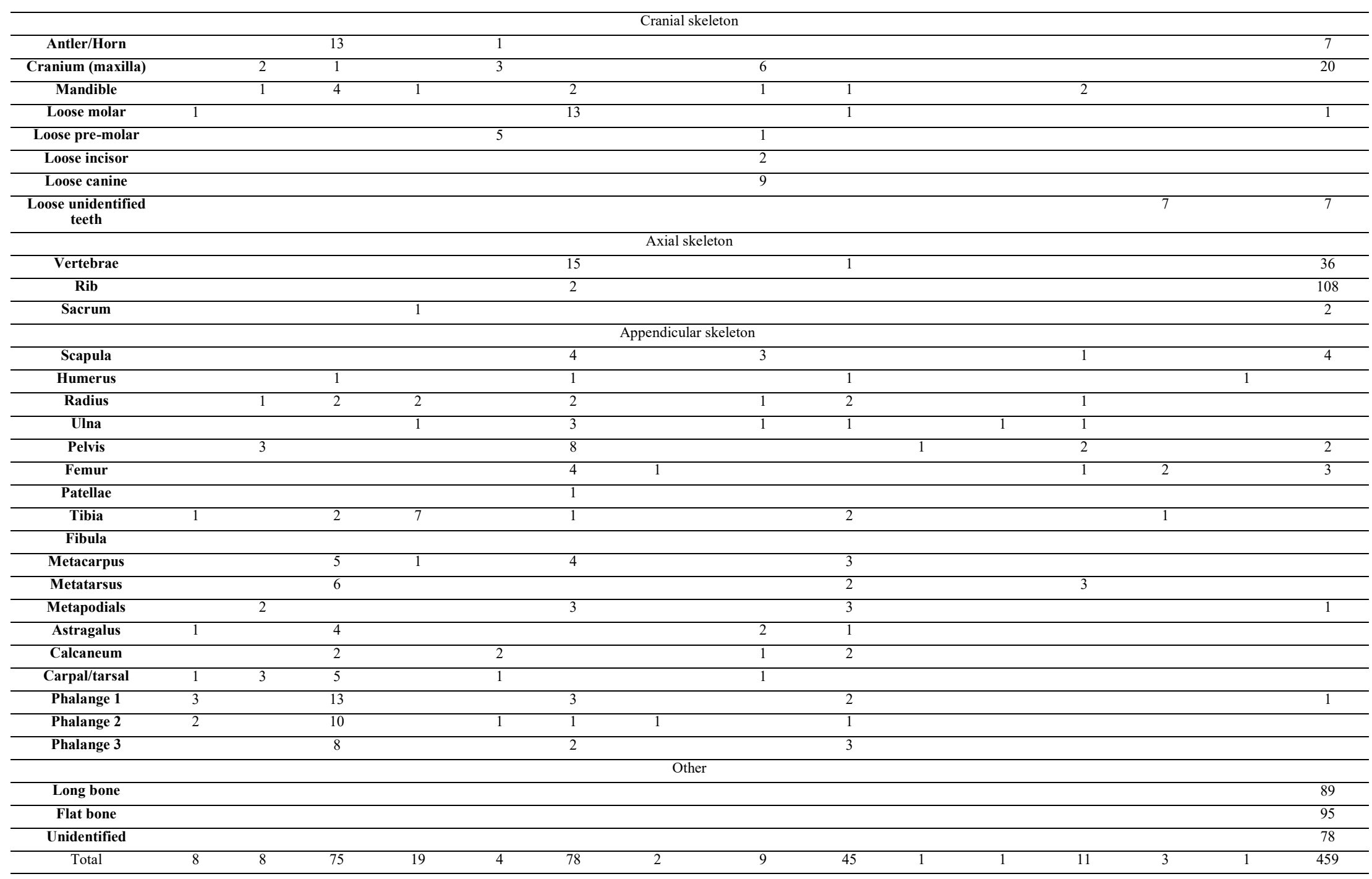


Table 6 - General Minimum number of individuals per taxa and age group calculated for the main species identifiedin Pit 50 with no distinction between Stratigraphic Units or Phases of infilling of Pit 50.

\begin{tabular}{|c|c|c|c|c|}
\hline Taxa & Infant & Juvenile & $\begin{array}{c}\text { Juvenile/ } \\
\text { Adult }\end{array}$ & Adult \\
\hline Bos taurus & & & 2 & 1 \\
\hline Capra hircus & 1 & 1 & & 2 \\
\hline Ovis aries & & & & 1 \\
\hline Ovis/Capra & & 1 & & \\
\hline Cervus elaphus & & 1 & & \\
\hline Sus domesticus & & 1 & 1 & \\
\hline Sus sp. & 1 & & & 1 \\
\hline Total & 2 & 4 & 3 & 5 \\
\hline
\end{tabular}

recovered, from [SU45]. Capra hircus horns, 1 occipital and 1 metatarsal were recovered in [SU33]. Ovis/Capra is less represented with 1 maxilla portion and 2 loose teeth. Interestingly, while Caprines decrease in representativeness, Sus becomes the predominant group. Both Sus domesticus and Sus sp. were identified by cranial, axial and appendicular elements. Smallsized animals cranial and axial fragments are common among taxonomically unidentified fragments.

During Phase 4 and Phase 5, faunal remains further diminish in quantity, especially in [SU22]. Oryctolagus cuniculus (2 metatarsals) and Sus sp. (2 metacarpal fragments, 1 scaphoid) were recovered from Phase 4 . In the latter, taxonomically unidentified bone and teeth fragments correspond mainly to small sized to medium/largesized weight groups. Finally, Phase 5 only had 1 small sized long bone fragment, 1 unidentified bone fragment, and 1 Vulpes vulpes pelvis fragment.

A general tendency to the reduction of the average size of faunal remains can also be seen from [SU56] to [SU22]. While the average maximum dimensions of Phase 1 is $54 \mathrm{~mm}$ and Phase 2 is $40,8 \mathrm{~mm}$, in Phase 3 it is reduced to $36,2 \mathrm{~mm}$, further diminishing in Phase $4(22,3 \mathrm{~mm})$ and Phase $5(31,7 \mathrm{~mm})$. Nonetheless, this seems to be related to the presence of several complete limbs in phases 1 and 2, although it can also be suggestive of the overall preservation between infilling phases. During Phase 2 a higher segmentation of the elements is evidenced and in the most recent phases besides being less abundant, faunal remains are more fragmentary.

Regarding completeness analysis, it was made on a total of 60 cortical tissue remains from phases $1(35 \%), 2(42 \%), 3(20 \%)$ and $4(3 \%)$. Results indicate that $77 \%$ have $<1 / 2$ of its original length and $73 \%$ have $<1 / 3$ of their original circumference. Fracture planes analysis was made on 163 planes, once more from phases 1 (33\%), 2 (39\%), 3 $(19 \%)$ and 4 (9\%) (Fig. 11). High representativeness of curved delineations, right degrees, and jagged surfaces is predominant, but longitudinal delineations, mixed degrees, and smooth surfaces are well represented. This is suggestive of fresh fracture (or probably some amount of burnt and post-boiling fracture - CÁCERES et al. 2002; OUTRAM 2002) but also fragmentation. Recent mechanical fractures, easily identified by the colour of the fracture planes, were recorded on $299(41,3 \%)$ remains but these where tentatively jointed whenever possible to reduce inflation of NISP values due to modern fractures.

Although $74,9 \%$ of the assemblage has a maximum dimension of $<5 \mathrm{~cm}$, complete records (117 or $16,2 \%)$ or records with preservation of $\geq 75 \%$ (63 or $8,7 \%$ ) are abundant. Among complete elements, phalanges (n 42, 35,9\%), carpals/tarsals (n 21, 17,9\%), loose teeth (n 13, 7\%) and vertebrae (n 15, 12,8\%) are common but long bones were also recorded. Most complete elements are from Phase 2 with $88(75,4 \%)$ records but [SU51] alone corresponds to $48(41 \%)$. Still, [SU56] from Phase 1 has a total of $21(17,9 \%)$ complete elements. This demonstrates that the assemblage is well preserved although the fracture and fragmentation of remains have occurred.

On the one hand, taphonomic indicators associated to the nutritive phase (Fig. 12) are better represented by the presence of cut marks in $4 \%$ of the assemblage, mainly in remains from [SU51] corresponding to Phase 2 where $14(48,3 \%)$ records with cut marks were identified. Part of the cut marks identified was recorded in tarsals and proximal parts of metapodials from Capra hircus, including the appendicular extremities in anatomical connection. Cut marks are the evidence of the butchering process (SEETAH 2008) that have less equifinality problems (LYMAN 1994) and are the fortuitous result of human behaviour (LYMAN 2005). Even if chop marks and complete sectioning were recorded, incisions are by far the predominant typology of cut marks (n 24, 82,8\%). Identified in carpals/tarsals (n 6), ribs (n 2), cranium fragments (n 2), scapulae (n 3) and vertebrae (n 4), besides long bones (n 5) and other axial (n 5) elements, their functional meaning (BunN 1991: 44) was related to the different stages of the butchering process, from skin and horn removal to disarticulation and posterior disconnections, filleting and evisceration, the latter being vestigial. The anthropogenic fracture was identified predominantly in long bone fragments from small to large weight groups (n 13, $68,4 \%$ ). Main indicators are percussion impacts (n 8), cortical extractions (n 5), stigma (n 2), but also 1 cortical flake and 1 possible percussion flake. Thermo-alteration, both in the form of burnt remains in different colour degrees (SHIPMAN et al. 1984) and possible boiling, were recorded with low abundances but the latter is very problematic in terms of identification since its physic-chemical signature can be mimitized by diagenesis (RoBERT et al. 2002; KoON et al. 2003; 2010; SolARI et al. 2015). With scarce representativeness, tooth marks were identified in two remains but are not indicative of a specific agent of modification.

On the other hand, remaining taphonomic indicators comprise the precipitation of manganese oxide $(22 \%)$ and vermiculations $(20 \%)$, almost en- 
tirely circumscribed to the early stages of affectation (Degrees 1 and 2) of the remains surfaces. Trampling that can occur during partial or total burial of remains (LYMAN 1994), concretions, and corrosions were also recorded but with very low frequencies. Some thoughts on the presence of weathering must be shared since it is commonly used as an "indicator" of sedimentation processes and/or the exposure (or re-exposure) of remains. It is a complex process (FERNÁNDEZ-JALVo et al. 2010) de- pendant of several factors (e.g., BEHRENSMEYER 1978; TAPPEN 1994; Trueman et al. 2004) that does not occur only during the sub-aerial phase but also in sub-surface context (LyMAN \& Fox 1989). In the case of Pit 50 faunal assemblage, $49(6,8 \%)$ remains had indicators of weathering but $39(79,6 \%)$ correspond to BEHRENSMEYER (1978) stage 1 and the other $10(20,4 \%)$ to stage 2 . This is suggestive of fast sedimentation of the faunal remains or a minimum re-exposure.

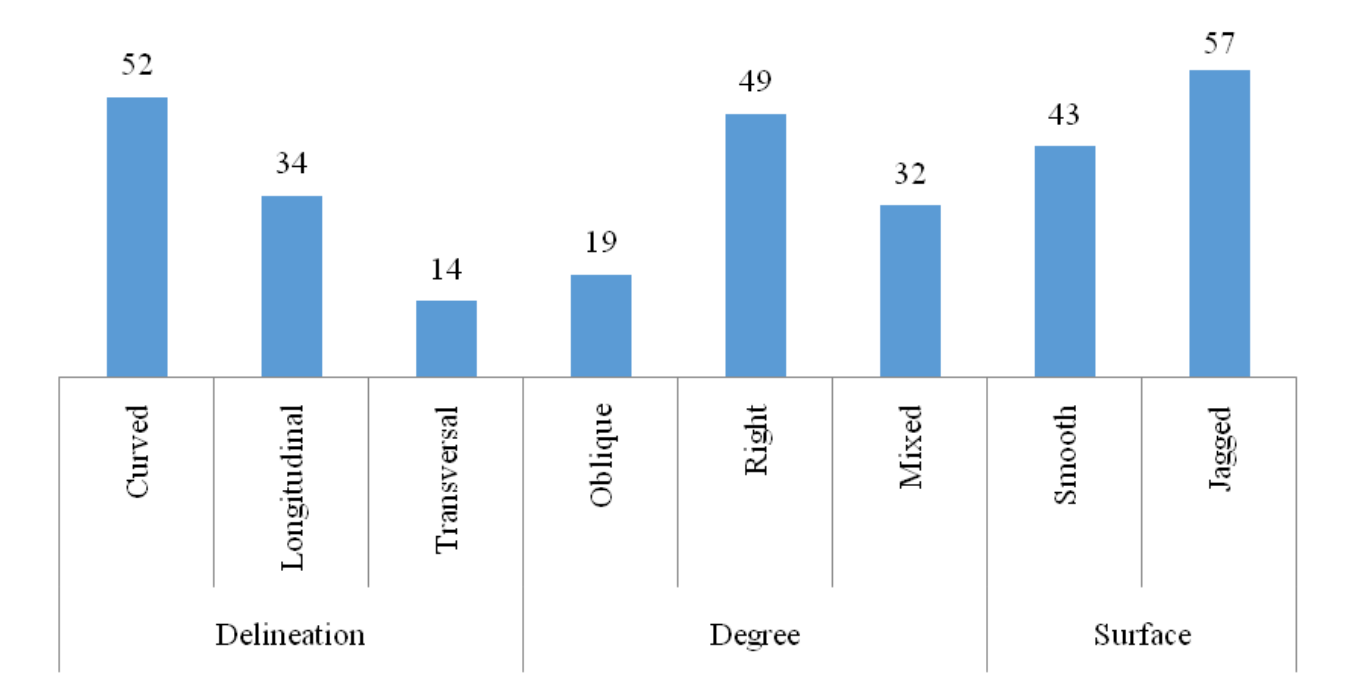

Fig. 11: Cortical tissue fracture plane analysis relative abundance (\%) from Pit 50 according to their delineation, degree and surface.

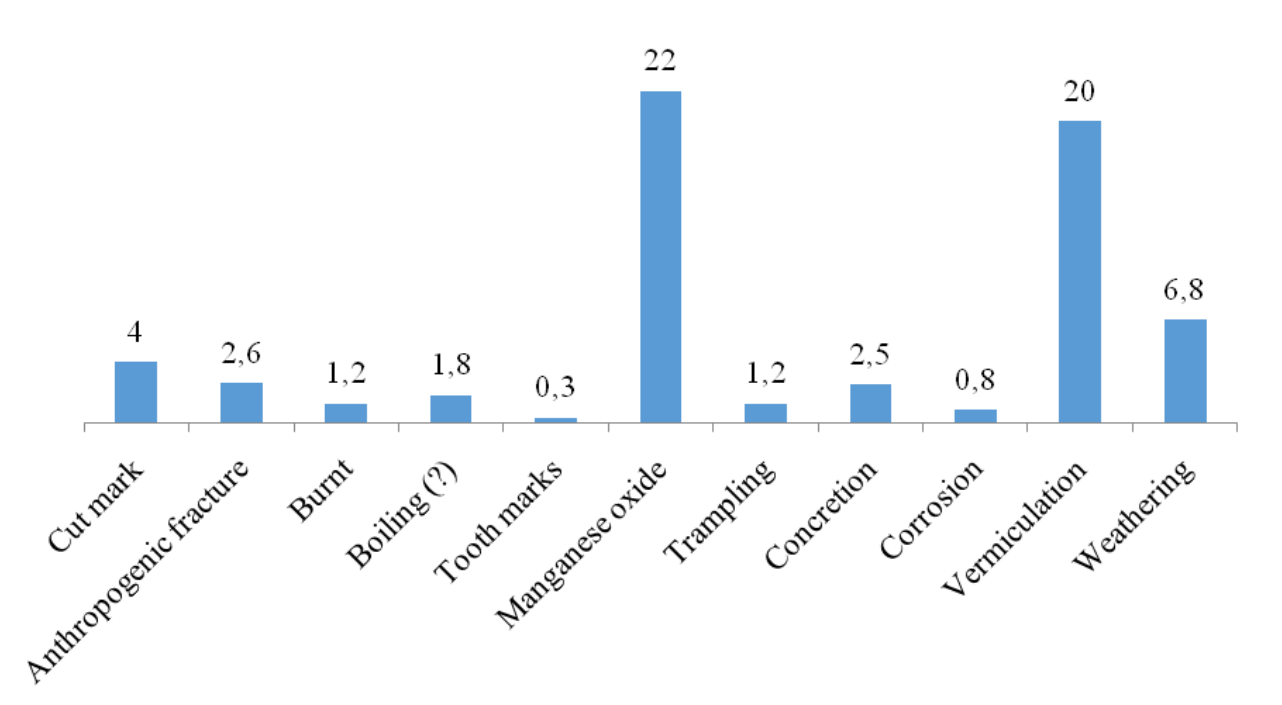

Fig. 12: Taphonomic indicators relative abundance (\%) from Pit 50 fauna assemblage. 


\section{CHRONOLOGY}

Three radiocarbon dates were obtained for Pit 50. One from the concentration of faunal remains in the first deposit (Phase 1 - SU56), other from the concentration of faunal connections (Phase 2 SU51) and a third from one of the latest layers of Phase 3 (SU31). There is also a date for the initial deposit of Ditch 10 (Table 7).

The calibrated dates show a significant overlapping between 2870 and $2580 \mathrm{cal} \mathrm{BC}$ at $2 \sigma$, and with percentages of $70 \%$ between $2780-2580 \mathrm{cal}$ $\mathrm{BC}$, falling mainly in the second quarter of the $3^{\text {rd }}$ millennium BC. Although the amplitude of the interval is about 200 years, the overlapping of the three dates suggests that the infilling of the pit was relatively rapid, what is consistent with the good preservation of most bones, that don't show signs of extended exposure.

Regarding the chronological relation between Pit 50 and Ditch 10, the available dates allow thinking that the initial filling of the ditch might be earlier than the filling of the pit, within the first quarter of the $3^{\text {rd }}$ millennium BC. A model assum- ing that priority of Ditch 10 provides a good agreement $\left(A_{\text {model }}=104.7\right)$ (Fig.13), but also suggests that they may have been in part coexistent. Because there is only one date for this ditch, corresponding to the first deposit, it is possible that the rest of the filling, and especially a re-cutting identified in the infillings, was contemporaneous of the pit's depositions.

In the global available chronological scenario of Perdigões (VALERA et al. 2014b; VALERA 2018 Fig. 3:2) the Ditch 10 is the older one of the Chalcolithic phase, dating from $2900-2750(85,6 \%$ probability). In fact, it provides one of the oldest dates for a Chalcolithic context at Perdigões, closely followed by Pit 25 (in the central area of the enclosures) and by Tomb 3, that also provides dates within the second and third centuries (still unpublished), showing a continuity of construction and occupation in the early $3^{\text {rd }}$ millennium BC. As to Pit 50, it falls into the chronological spectrum of the initial infillings of Ditches 3 and 4 (more interior than Ditch 10) and of the earlier uses of Tomb 1, Tomb 2 and Tomb 3, located in the eastern limits of the site (VALERA et al. 2014b).

Table 7 - Radiocarbon dates for Sector O of Perdigões - Pit 50 and Ditch 10

\begin{tabular}{cccccc}
\hline Feature & SU & Sample & Lab Ref & Date BP & Date cal 2 $\sigma$ \\
\hline Pit 50 & 31 & Fauna & ICA17B/1146 & $4120 \pm 30$ & $2870-2800(25,1 \%) 2780-2580(70,3 \%)$ \\
Pit 50 & 51 & Fauna & ICA17B/1144 & $4140 \pm 30$ & $2867-2802(23,3 \%) 2777-2620(72,1 \%)$ \\
Pit 50 & 56 & Fauna & ICA17B/1145 & $4110 \pm 30$ & $2870-2800(24,1 \%) 2760-2580(71,3 \%)$ \\
Ditch 10 & 36 & Fauna & ICA15T/1017 & $4220 \pm 30$ & $2905-2853(42,8 \%) 2813-2743(42,8 \%) 2727-2696(9,9 \%)$ \\
\hline
\end{tabular}

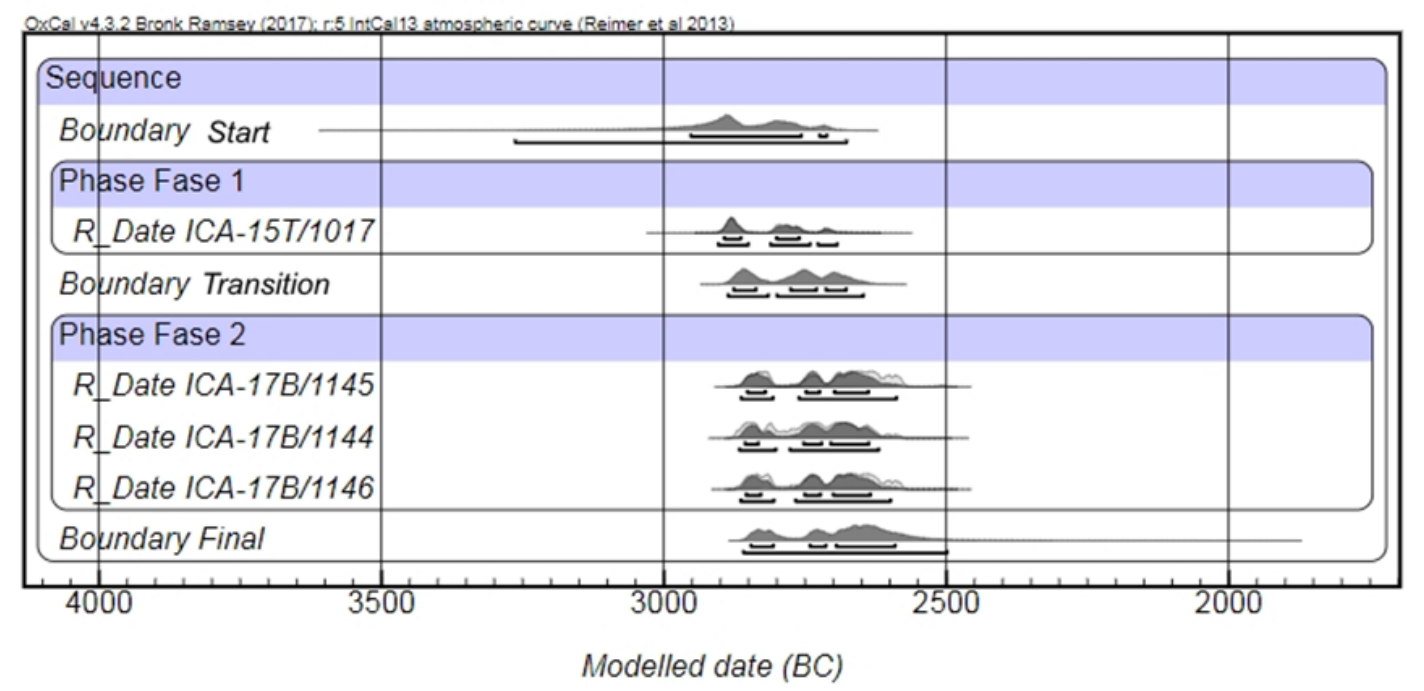

Fig.13: Model for the radiocarbon dates from Ditch 10 (considered as Phase 1) and Pit 50 (considered as Phase 2). 


\section{DISCUSSION}

Pit 50 is one among the hundred already excavated in Perdigões (a small part in face of the thousands that can be perceived in the magnetogram of the site) and it is one of the largest identified in the Chalcolithic phase. Its interest rests in the combination between its location, the infilling sequence and some peculiarities of the depositions, namely regarding the two major components: pottery and faunal remains.

It is in front of a gate in Ditch 10 aligned with the sunset in the equinoxes and generally in front of the western double gate in Ditches 1 and 2. According to available absolute chronology, Ditch 10 is some centuries earlier, so this spatial relation between gates suggests that the construction of the later double gate might have taken in consideration a previous pathway related to the entrance in Ditch 10 . Pit 50 would be in that pathway.

Its infilling sequence presents several interesting aspects that are unique at Perdigões so far.

First, the great amount of pottery sherds, mainly of small dimensions, with a residual refitting of fragments. This circumstance suggests selection, for it is not credible that a random sample of pottery sherds of such size, collected somewhere as refuse, did not present more refitting cases or parts from the same pots. This situation has already been noted at Perdigões in the Late Neolithic Ditch 8 and Ditch 12, where, among the several hundred fragments of pottery deposited horizontally in the closing deposits of the fillings, no refitting was detected (VALERA 2018: 55-56; 63-65). The selection of pottery sherds, used in specific depositions, seems to have been a recurrent practice at Perdigões.

Secondly, the distribution of pottery sherds along the stratigraphy in terms of quantity and level of fragmentation / completeness suggests, as has already been noticed (VALERA 2019b), intentionality and underlines the importance of segmentation as a structural social practice, calling for a semantic approach. The first three infilling phases integrate small fragments of pottery, with sizes within classes 1 to 3 . The exception is one larger sherd of a low carinated bowl. But these three phases present an alternant rhythm: the first with 267 fragments, the second phase more than duplicates (575 fragments), and the third phase returns to a similar level of the first (239 fragments). Then, at phase four, when the profile of the pit shrinks, the deposition of fragments abruptly ends (just a rim was recorded) and three halves of vessels ware deposited. Finally, the infilling ends with a construction of a "pedestal" of small rocks, the deposition of a complete pot over the stones, and the formation of two deposits, again with more than a hundred small sherds and a schematic anthropomorphic figurine.

The incorporation of pottery in this infilling sequence does not seem to be random. It shows a trajectory from rhythms of deposition of highly fragmented sherds with no refitting, to a moment of depositions of halves, and finally to a moment of deposition of a complete pot over a built "pedestal" of stones (but accompanied again by small pottery sherds) (Fig.6). It seems to assume a metaphoric meaning regarding the relation part / whole (VALERA 2019b), establishing a sequence of progressive passage from plurality (only small sherds) to unity within plurality (the whole in a pedestal amongst fragments). The intermediate stage, as a sort of metamorphosis between these two conditions, shows only one small fragment and three halves of recipients. This occurs in a specific level of the pit, when the walls shrink before open again in the last segment, as if change in pottery dispositions accompanied the changes in the pit's morphology.

Some sort of codification emerges from the analyses of the vertical distribution of pottery, and the sequence seems to assume the form of text, also presenting an aesthetic value (PoLLARD 2001), both resulting from the ways the different materials were combined and arranged in the depositions along the pit. The eventual effectiveness of the discourse was not just resting on the contents but also in the care putted in the design of the depositions.

About the meanings, though, we can only speculate, and the elements that integrate de depositions certainly had many genres of activity that they referred to simultaneously (RoBB 2010). But taking in consideration some of the observed internal relations, it could be suggested that the use of pottery in this filling sequence could stand as a metaphor for the social relations in construction in the period (first half of the $3^{\text {rd }}$ millennium $\mathrm{BC}$ ) and in the site (that has been interpreted mainly as an aggregation centre for social negotiation and interaction, ceremonial practices, and identity management - VALERA et al. 2014a; 2015; VALERA 2017) Naturally, this hypothesis cannot be demonstrated, and its value stands in terms of the plausibility it may acquire in face of the information that is being obtained for the Perdigões, where several contexts have been providing evidences of practices of social emulation and identity management (VALERA et al. 2015; VALERA 2017) that could impregnate and be expressed by different contexts, from the most complex funerary structure, to the ways a pit is filled.

Interestingly, the faunal distribution also presents variance in the sequence of infilling and certain levels of correlation with the pottery distribution can be detected. Considering the relative abundance of remains for the different phases, an important difference is also observable between phases 1 to 3 and the more recent phases 4 and 5 (the ones of the halves and complete pot). The latter, altogether, represent only $6,6 \%$ of the assemblage, which is less than any other phase alone, revealing a performance similar to the pottery sherds. Concerning the species representativeness, Caprines, including Ovis aries, Capra hircus and Ovis/ Capra, are the most abundant group on phases 1 and 2. During Phase 2, we start to see a rise on the abundance of Sus, including Sus domesticus that by Phase 3 is the predominant group in detriment of Caprines.

Regarding the elements identified, some particularities are of interest: in Phase 1, part of 
an Ovis/Capra skeleton with some vertebrae in anatomical connection was recovered; several horns of Capra hircus, the majority having been removed from the cranium as indicated by the segmentation marks on the base of the horns were recorded in Phase 1 and 2; one Bos sp. mandible was deposited in Phase 3 without teeth and only one Bos taurus tooth $\left(\mathrm{M}^{1}\right)$ was recovered in the pit, from Phase 2; and several extremities of the appendicular skeleton of Capra hircus, both posterior and anterior, were identified in Phase 2.

In a general perspective, some remains from specific species, namely Caprines, were found with high preservation while others, as Sus, were rarely complete. Also, almost $15 \%$ of the NISP $(52 \%$ of the MNE excluding taxonomically unidentified remains) correspond to carpals/tarsals, metacarpals/ metatarsals, and phalanges. Limb extremities are clearly well represented both in terms of Number of identified specimens and the Minimum number of elements. Other appendicular elements, although identified, are not as well represented, especially for taxa other than Caprines and Sus. Bos, for example, is better represented by limbs extremities, which correspond to $9(65 \%)$ of the Bos remains.

No preference for elements laterality was identified. A Sus sp. cranium portion maintaining a right occipital was recovered in [SU45] (Phase 3) and something similar was identified for [SU55] (Phase 1), this time with a left occipital. Although it is not possible to entirely ascertain if both portions are from the same element, that possibility must be taken in consideration and would indicate the separation of a Sus sp. cranium in different phases of the pit 50 infilling. We must take into account the presence of vertebrae (n 36, 4,9\%) and rib (n 108, 14,9\%) fragments unidentified taxonomically, as well as unidentified long (n 89, $12,3 \%$ ) and flat (n 95, 13,1) bone fragments, but their dimensions hardly explain the underrepresentativeness of some anatomic elements or, at least, the lesser fracture of appendicular extremities. It seems that specific parts of specific animals were deposited, and its explanation might go beyond the mere economic value and be related to the ontological status and relations between humans and animals during the Neolithic (INGOLD 1988; VALERA 2012).

As for the ways in which animals were processed, indicators of anthropogenic breakage, cut marks or thermo-alteration are vestigial or absent in phases 4 and 5 . Even if present in the quantitatively important phase 3 , they are not as expressive in comparison with phase 2 or phase 1 . Although phase 1 comprises a relevant abundance of the total anthropogenic breakage and cut marks, their higher frequency occurs during phase 2. In this sense, nutritive phase taphonomic indicators dispersion among the assemblage generally follows faunal remains abundance in the pit infilling sequence, i.e. the higher the amount of fauna remains the higher the number of indicators recorded. To some extent, this might relate to taphonomic indicators identifiability, since faunal remains size changes in the infilling sequence as well, possibly hindering indicators observability.
The phases where Caprines are the most relevant species, are also where most nutritive phase indicators were recorded. In the one hand, during phase 2 we have distal extremities and cranial elements of Caprines with a high incidence of cut marks but commonly complete; on the other hand, breakage and thermo-alterations occurs mainly in unidentifiable remains of small-sized animals, which could include unidentified Caprine remains. This might be suggestive of the higher breakage of proximal limb elements. In fact, Caprine distal appendicular elements (metapodials, carpals/tarsals, phalanges) are normally complete, the same occurring with suids and bovids phalanges found during phase 2. This is not observable in phase 3 where complete elements are residual, neither in phase 1 , where several complete elements were recorded but correspond mainly to Caprine vertebrae and loose teeth. In pit 50 infilling, Caprines seem to be represented by a certain "completeness" that to some extent differentiates them from other species: suids or even bovids complete bones are circumscribed to phalanges and carpals/tarsals, while Caprines not only comprise complete cranial, axial and appendicular elements, but also axial and appendicular anatomical connections.

Concerning the presence of appendicular extremities in anatomical connection, this occurrence has already been noted in funerary contexts from Late Neolithic to the middle Bronze Age in South Portugal (VALERA \& COSTA, 2013a; CosTA \& BAPTISTA, 2014). In Perdigões this association occurs in two Late Neolithic pit burials, where two paws of $S u s s p$. were recorded (MORENO GARCÍA \& CABAÇO 2009; VAlERA \& Godinho 2009) and in Chalcolithic Tomb 1, where a limb of a Vulpes vulpes was deposited in the closing level of the chamber (CABAÇO 2012; VALERA \& COSTA 2013a). However, this association is mainly found in Bronze Age contexts (41 of the 46 registered funerary contexts with animal limb depositions in VALERA, Costa (2013a), and represents mainly the Bos species.

In fact, the deposition of ovicaprid limb parts in anatomical connection is rare in the region, and although loose phalanges were used in Late Neolithic funerary contexts (VALERA \& COSTA 2013b), the depositions of complete paws of these animals are infrequent. So, this context of Pit 50 has a certain degree of uniqueness. Here, the depositions are not associated with a funerary context, and they occur in a specific moment of the infilling of the pit, in phase 2: after the construction of a semicircular alignment of stones and the formation of an inner and an outer deposit with some pottery and faunal remains (Fig. 3: G), the numbers of faunal remains increase and the fragments of pottery duplicate. But the fauna is mainly from [SU51], where the pottery has a lower presence, and was covered by [SU50], that has the major concentration of pottery sherds (Figure 9) and a small number of bones. So, phase 2 has a clear internal sequence of depositions where bones and pottery sherds have alternating roles.

Apart from the limbs, two situations deserve mention within the fauna depositions. First the seg- 
mentation and deposition of horns of Capra hircus, namely the pair in [SU51], deposited side by side, but with points facing opposite directions (Figure $5)$. This circumstance has already been noted and debated in the context of other depositions (of human and animal remains) in Perdigões that also seem to invoke the opposites (VALERA 2019b: 2324) and a similar situation occurs in Ditch 1, where two Bos $s p$. horns were deposited with opposite directions (MÁrquez et al. 2011b, Fig.7). This evocation of oppositions, that is perceived in many prehistoric contexts (through the use of colour, texture, size, orientation, etc.), may appear as a way of transforming the dichotomies (oppositions that are not mutually implicated) in dualisms (oppositions that are mutually implicated). That is, a way of overcoming paradoxes that was designated by "coincidentia oppositorum" (SCHWARZ 2018: 20 ), a characteristic attributed to pre-modern societies capable of generating an ability to harmoniously live and express contradictory experiences, perceptions and conceptions.

The other is the deposition of the Bos mandible over a layer of stones integrating a large schist slab. Note that the mandible had no teeth and only one Bos tooth was recovered in the pit, in an earlier layer, so it would be toothless and probably dry when deposited in the pit. Depositions of isolated mandibles have been noticed in other Chalcolithic contexts at Perdigões (as in late Middle Neolithic Pit 64 - Valera 2018, or in Ditch 7) and in other Chalcolithic contexts (CARDOSO 2009), showing a significant use of this particular part of the animal skeleton. Inclusively, in pit 84 of Perdigões, two halves of mandibles, one from a pig and the other from a horse, were deposited together, but pointing opposite directions (VALERA 2019b). A synthesis, in a same deposition, of the referred elements/ circumstances: deposition of mandibles, segmentation in halves, opposing directions.

In overall, Pit 50 infilling involved a set of options, decisions and practices that can hardly be reduced to a random accumulation. Naming it, though, is not easy and indisputable, mainly because the terminology related to intentional depositions is not always clear and well defined. In the revision done by OSBORNE (2004), he listed several terms: dedication (emphasizing the importance of given and the permanence of the gift), offering (focuses more in the act of giving itself, than in the gift), votive (traducing a link to prior vows, commitments or relations), hoards (manly traducing assemblages of similar and related objects), or simply deposit (traducing some sort of undetermined intentionality). To these we could add squander (highlighting the simultaneous act of exhibition and extraction of goods from living circuits), sowing (traducing cyclical perceptions of time and life, where the past is renewal by the incorporation of the old within the new - ELIADE 1969; 2016; BRÜCK 1999) or even compensation (by focus more in the reciprocity involved in the given).

In the present case, we should add to the equation the specific location of the pit in front of a gate as part of the structure's agency. Gates are structural elements in the organization of space and of the ways space is experienced and coursed, for they are the links and transitions between compartmented areas and the status/conditions they implicate. By doing so, they became points of metamorphosis through passage, places of paradox where the spatial dualities meet and, because of that, of great symbolism (ELIADE 2016: 34).

The available chronology indicates that the ditch might be a bit earlier than the pit, so to the later we can attribute de condition of being outside the enclosure. Even if the ditch was partially filled, it would be perceptible and still demarcating an inside and an outside. The fact that a gate was created in the later ditches 1 and 2, just in front of the gate of Ditch 10, is indicative that a previous pathway to the centre of the enclosures was still active. So, it could be suggested a connection to activities and practices related to this proximity to a point of transition, of change of condition, which the sequence of depositions also exhibit. Events could occur before entering the enclosure in certain periods of the year, prescriptions could have to be met or reinterpreted before transposing the gate, generating practices of deposition that would consist in agency of day-to-day level and simultaneously encoding and reproducing aspects of the social and ideologic structure of the times and of the place.

In this context, specific materials were called to play active parts in a set of action, a gate, that implicates the passage from one condition to another. In that set of action, people, specific animals and animal remains, specific objects and specifically located structures were combined in relational terms, generating a context of multiple agency (Fowler 2004; RoBb 2010).

Levels of intentionality can be observed in the practices of deposition occurred in Pit 50 that, together with the pit's location in a passage set of action, seem to assume a discursive status. In that sense, it is analogous to other pit depositions in Perdigões, where material culture patterning is intentionally created, symbolically meaningful and actively engaged, as is the case of Pit 84 , with the structure depositions of animal jaws (VALERA $2019 b$ ) or of Pit 94, with the depositions of crucibles and pots within pots. Therefore, Pit 50 can fall into the category of "odd deposit" (GARRow 2012), differing from some other pits excavated in Perdigões which infillings seem to result of more everyday activity.

It is, though, just one more example of the diversity of expressions that depositional practices assume in Perdigões. In fact, mundane activities do not imply the lack of symbolic, cosmological or ideological significance, for they may respond to cultural and social conventions, resulting in unconsidered and unintended reproduction of social structures and symbolic meanings (THOMAs in GARROw 2012). The simple selection of materials to be incorporated in pits and ditches, when and where, may respond to meaningful prescriptions that are not always followed deliberately, but are embedded in daily practices occurring in different sets of action. For instance, loom-weights were kept out of ditch depositions during the earlier 
phases of the $3^{\text {rd }}$ millennium $\mathrm{BC}$, and incorporated later (DALTON \& Selby 2019), in contexts that do not present any strangeness.

Those levels of unawareness, though, are also present and mixed with the intended and deliberated, as agency is a duality that integrates action and the fields of action with the conditioning of structural prescriptions expressed by the habitus (Bourdieu 1977; Giddens 2000; Barrett 2001). So, although presenting a unique patterning of depositions, possibly with specific meanings and with particular ranges of agency, Pit 50 integrates a generalized practice of structured depositions, with different levels of intentionality and unconscious conditioned behaviour, that characterized Perdigões ditched enclosure throughout its long biography.

\section{FINAL REMARKS}

The performative perception of society, that is to say, a construction "achieved in practice by all actors" (STRUM \& LATOUR 1987: 785), involves a growing diversity of circumstances and procedures that interfere in social relations, expressing them, reproducing them, and making them more complex. The structured or selective depositions, in each of the variants considered above, are amongst those practices that help to outline the Neolithic and Chalcolithic societies. They are actions through which human agency operates at a small-scale level, but related to wider social, economic and ideological structures, showing that agency and structure are a dualism (not a dichotomy) that cannot be addressed separately (JOHNSON 1989; DobRes \& RoBb 2000; Giddens 2000; Barrett 2001). In Perdigões these practices are recurrent throughout the long biography of the site. We can see them inside the early ditches (VALERA 2018) or in the later occupations, in features like Cairn 1 (BAsílio \& CABAÇO 2019), where faunal remains, possibly resulting from feasting ceremonies, were deposited in a pit that was then covered with a large agglomeration of stones and incorporating a small menhir. Acting as mnemonic devices, propitiatory practices, metaphors for social relation and identity management, these contexts, when analysed in detail, talk about a more fluid and relational ways of being in the world. They occur as singular forms of express and simultaneously produce the Neolithic habitus.

\section{Acknowledgments}

This research was done in the context of the Global Archaeological Research Program of Perdigões, directed by the Research Unit (NIA) of Era Arqueologia SA., and of the project PTDC/EPH-ARQ/0798/2014, financed by the Portuguese Science Foundation. The authors thank the comments and the contributions of the reviewers.

\section{REFERENCES}

Albarella, U.; Davis, S.; Detry, C.; Rowley-Conwy, P. 2005."Pigs of the "Far West": the biometry of Sus from archaeological sites in Portugal. Anthropozoologica 40: 27-54.
AlmeIDA, N.J. 2017.Zooarqueologia e tafonomia da transição para a agro-pastorícia no baixo e médio vale do Tejo.Arkeos 44. Mação,Instituto Terra e Memória.

Barrett, J. 2001. Agency, the duality of structure, and the problem of the archaeological record. In: I. HODDER (Ed.) Archaeological Theory Today. Oxford. Polity: 140-64.

Basílio, A.C.; CABAÇO, N. 2019.An end that perpetuates: a cairn from the end of the 3rd milenniumbc at perdigões, In: A.C. Valera (Ed.), Fragmentation and depositions in Pre and Proto-Historic Portugal, Lisboa, NIA-Era Arqueologia: 105-123.

BeHRenSMEYER, A.K. 1978.Taphonomic and ecologic information from bone weathering.Paleobiology, 4(2): 150-162.

Bourdieu, P. 1977. Outline of a theory of practice. Cambridge. CUP.

BRonk RAMSEY, C. 2009. Bayesian analysis of radiocarbon dates.Radiocarbon 51 (1): 337-360.

Bronk Ramsey, C. 2013. Recent and planned developments of the program OxCal. Proceedings of the 21st International Radiocarbon Conference, Radiocarbon 55 (2-3): 720-730.

BRÜCK, J. 1999. Houses, lifecycles and deposition on Middle Bronze Age settlements in southern England. Proceedings of the Prehistoric Society 65: 145-66.

BRÜCK, J. 2006. Fragmentation, Personhood and Social Construction of Technology in Middle and Late Bronze Age Britain. Cambridge Archaeological Journal. 16(3): 297-315.

Bull, G., Payne, S. 1982. Tooth eruption and epiphyseal fusion in pigs and wild boar. In: B. Wilson, C. Grigson, S. \& Payne, S. (Eds.), Ageing and sexing animal bones from archaeological sites, BAR British Series 109, Oxford, Archaeopress: 55-72.

BunN, H.T. 1991. A taphonomic perspective on the archaeology of human origins. Annual Review of Anthropology 20: 433-467.

CABAÇO, N. 2012. Restos faunísticos em contexto funerário nos Perdigões, Reguengos de Monsaraz (Sepulcros 1 e 2). In:Actas das IV Jornadas de jovens em investigação arqueológica, Promontória Monográfica 16 , Faro.

Cáceres, I.; Bravo, P.; Esteban, M.; Expósito, I.; SaladiÉ, P. 2002. Fresh and heated bone breakage: an experimental approach. In: M., De Renzi, M. Pardo, M. Belinchón, M. Peñalver, E. Montoya \& P., Márquez-Aliaga (Eds.), Current topics on taphonomy and fossilization, New York, John Wiley and Sons Inc: 471-478.

Cardoso, J.L. 2009. O povoado Pré-Histórico do Carrascal (Oeiras) e os rituais associados a grandes bovídeos. Estudos Arqueológicos de Oeiras 17: 357-370.

Chapman, J. 2000. Fragmentation in Archaeology. People, Places and Broken Objects in the Prehistory of South Eastern Europe, London, Routledge.

Chapman, J.; Gaydarska, B. 2007. Parts and Wholes. Fragmentation in Prehistoric Context, Oxford, Oxbow books.

Costa, C.; Baptista, L. 2014. The inclusion of faunal remains in Bronze Age funerary practices in Southern Portugal. Montinhos 6 - a case study. In: C. DetrY \& R, Dias (Eds.), Proceedings of the First Zooarchaeological Conference in Portugal, Bar International Series S2662, Oxford, Archaeopress: 33-36. 
Dalton, S.; Selby, E. 2019. Loom weights from Chalcolithic and Early Bronze Age Perdigões (Alentejo, Portugal). Apontamentos de Arqueologia e Património 13: 27-34.

DAvis, S.J.M. 1996. Measurements of a group of adult female Shetland sheep skeletons from a single flock: a baseline for zooarchaeologists. Journal of Archaeological Science 23: 593- 612.

Dobres, M.-A.; RoBB, J. 2000.Agency in Archaeology. Paradigm or platitude? In: M.-A. Dobres \& J. RoBB (Eds.), Agency in Archaeology, London, Routledge: 3-17.

Driesch, A. Von Den1976. A Guide to the Measurement of Animal Bones from Archaeological Sites (as developed by the Institut für Palaeoanatomie, Domestikationsforschung und Geshchichte der Tiermedizin of the University of Munich). Peabody Museum Bulletin 1. Peabody Museum of Archaeology and Ethmology, Harvard University.

Eliade, M. 1969.Le mythe de l'éternel retour. Archétypes et répétition. Paris, Gallimard.

Eliade, M. 2016.O Sagrado e o Profano. Lisboa, Relógio D’Água.

Fernández-Jalvo, Y.; Andrews, P.; Pesquero, D.; Smith, C.; Marín-Monfort, D.; Sánchez, B.; Geigl, E.M.; Alongo, A. 2010.Early bone diagenesis in temperate environments Part I: Surface features and histology. Palaeogeography, Palaeoclimatology, Palaeoecology 288: 62- 81.

Fowler, C. 2004. The Archaeology of Personhood. An Anthropological Approach, Routledge, London.

GARrow, D. 2012. Odd deposits and average practice. A critical history of the concept of structured deposition. Arhaeological Dialogues 19(2): 85-115.

Giddens, A. 2000.Dualidade da Estrutura. Agência e Estrutura. Oeiras, Celta.

Grant, A. 1982. The use of tooth wear as guide to the age of domestic ungulates. In: B. Wilson, C. GRIGSON \& S. PAYNe, S. (Eds.), Ageing and sexing animal bones from archaeological sites. BAR British Series 109, Oxford, Archaeopress: 91-198.

Harrell, K.; Driessen, J. (Eds.) 2015. Thravsma. Contextualising the Intentional Destruction of objects in the Bronze Age Aegean and Cyprus. AEGIS, 09 Presses Universitaires de Louvain.

IngOLD, T. 1988. What is an Animal?. Unwin Hyman, London.

Jorge, S.O.; Oliveira, M.L; Nunes, S.A.; Gomes, S.A. 1998-99. Uma estrutura ritual com ossos humanos no sítio Pré-Histórico do Castelo Velho de Freixo de Numão $\left(\mathrm{V}^{\mathrm{a}} \mathrm{N}^{\mathrm{a}}\right.$ de Foz Côa). Portugália. Nova Série. XIX-XX: 29-70.

JohnSON, M.H. 1989. Conceptions of agency in archaeological interpretation. Journal of Anthropological Archaeology 8: 189-211.

Koon, H.E.C.; O’Connor, T.P.; Collins, M.J. 2010. Sorting the butchered from the boiled. Journal of Archaeological Science 37: 62-69.

Koon, H.E.C.; Nicholson, R.A.; Collins, M.J. 2003. A practical approach to the identification of low temperature heated bone using TEM. Journal of Archaeological Science 30: 1393- 1399.

Lago, M; Duarte, C; Valera, A.; Albergaria, J.; AlmeiDa, F.; Carvalho, A. 1998. Povoado dos Perdigões (Reguengos de Monsaraz): dados preliminares dos trabalhos arqueológicos realizados em 1997. Revista
Portuguesa de Arqueologia 1(1): 45-152.

Lemoine, X.; Zeder, M.A.; Bishop, K.J.; Rufolo, S.J.2014. A new system for computing dentition-based age profile in Sus scrofa. Journal of Achaeological Science 47: 179-193.

Lyman, R.L. 1994. Vertebrate Taphonomy. Cambridge University Press, Cambridge.

LYMAN, R.L. 2005. Analyzing cut marks: lessons from artiodactyl remains in the northwestern United States Journal of Archaeological Science 32: 1722-1732.

Lyman, R.L. 2008. Quantitative Paleozoology, Cambridge University Press, Cambridge.

LYMAN, R.L.; FOX, G.L. 1989. A critical evaluation of bone weathering as an indication of bone assemblage formation. Journal of Archaeological Science 16 293-317.

Márquez, J.E.; Valera, A.C.; Becker, H.; Jiménez, V. SuÀrez, J. 2011a. El Complexo Arqueológico dos Perdigões (Reguengos de Monsaraz, Portugal) Prospecciones Geofísicas - Campaña 2008-09. Trabajos de Prehistoria 68(1):175-186.

Márquez, J.E.; SuARÉZ, J.; Mata, E.; JimÉnez, V.; CARo, J.L. 2011 b. Actividades arqueológicas de la universidad de Málaga en el complexo arqueológico de Perdigões (Reguengos de Monsaraz, Portugal). Trienio 2008-2010. Apontamentos de Arqueologia e Património7: 33-40.

MCFADYEN, L. 2006. Material culture as architecture - Neolithic long barrows in Southern Britai., Journal of Iberian Archaeology 8: 91-102.

Moreno García, M.; CabaÇO, N. 2009. Restos Faunísticos em contexto Funerário: Fossas 7 E 11dos Perdigões (Reguengos de Monsaraz). Apontamentos de Arqueologia e Património 4: 11-14.

OsBorne, R. 2004. Hoards, votives, offerings: the archaeology of the dedicated object. World Archaeology 36 (1): $1-10$.

Outram, A.K. 2002. Bone fracture and within bone nutrients: an experimentally based method for investigating levels of marrow extraction. In: P. MiracLE \& N. Milener (Eds.), Consuming passions and patterns of consumptions, Cambridge, McDonald Institute for Archaeological Research:51-64.

Payne, S. (1987). Reference codes for wear states in the mandibular cheek tooth of sheep and goats. Journal of Archaeological Science 14: 609-614.

PAYNE, S.; Bull, G. 1988. Components of variation in measurements of pig bones and teeth, and the use of measurements to distinguish wild form domestic pig remains. ArchaeoZoologia II (1-2): 27-66.

Pollard, J. 2001. The Aesthetics of Depositional Practice. World Archaeology 33(2): 315-333.

Reimer, P.J.; Bard, E.; Bayliss, A.; Beck, J.W.; BlackWell, P.G.; Bronk Ramsey, C.; Grootes, P.M.; Guilder-Son, T.P.; Haflidason, H.; Hajdas, I, Hattz, C.; Heaton, T.J.; Hoffmann, D.L.; HogG, A.G.; Hughen, K.A.; Kaiser, K.F.; Kromer, B. Manning, S.W.; Niu, M.; ReImer, R.W.; RichARDS, D.A.; ScotT, E.M.; Southon, J.R.; StaFF, R.A.; Turney, C.S.M.; VAn Der Plicht, J.; 2013. IntCal13 and Marine 13 radiocarbon age calibration curves 0e50,000 years cal BP, Radiocarbon 55 (4) $1869-1887$

ReITZ, E.J.; WING, E.S. 2008. Zooarchaeology. Cambridge University Press, Cambridge. 
Richards, C.; Thomas, J. 1984. Ritual activity and structured deposition in Later Neolithic Wessex, In: R. Bradley, J. Gardiner (Eds) Neolithic studies. A review of some current research. Oxford: 189-218.

RoвB, J.E. 2010. Beyond Agency. World Archaeology 42(4): 493-520.

Roberts, S.J.; Smith, C.I.; Millard, A.; Collins, M.J. 2002. The taphonomy of cooked bone: characterizing boiling and its physico-chemical effects. $A r$ chaeometry 44(3): 485-494.

Richards, C.; Thomas, J. 1984. Ritual activity and structured deposition in Later Neolithic Wessex. In: R. BRADLEY \& J. Gardiner (Eds), Neolithic studies. A review of some current research, Oxford: 189-218.

Santos, B.S. 1999. Pela mão de Alice. O social e o político na pós-modernidade, Porto, Edições Afrontamento.

Schwarz, F. 2018. Mitos, ritos e símbolos. Antropologia do Sagrado, Lisboa, Nova Acrópole.

SeEtah, K. 2008. Modern analogy, cultural theory and experimental replication: a merging point at the cutting edge of archaeology. World Archaeology 40 (1): $135-150$.

Shipman, P.; Foster, G.; Shoeninger, M. 1984. Burnt bones and teeth: an experimental study of color, morphology, crystal structure and shrinkage. Journal of Archaeological Science 11: 307-325.

Solari, A.; Olivera, D.; Gordillo, I.; Bosch, P.; Fetter, G.; Lara, V.H.; Novelo, O. 2015. Cooked bones? Method and practice for identifying bones treated at low temperature. International Journal of Osteoarchaeology 25: 426-440.

TAPPEN, M. 1994. Bone weathering in the tropical rain forest. Journal of Archaeological Science 21: 667-673.

TÂrleA, A. 2008. The concept of 'Selective Deposition'. PEUCE, s.n., VI: 63-132.

TILlEy, C. 1991. Metaphor and Material Culture, London, Wiley-Blackwell.

Strum, S.S.; LAtour, B. (1987). Redefining the social link. Social Science Information 26: 783-802.

Trueman, C.N.G.; Behrensmeyer, A.K.; Tuross, N.; WeINER, S. 2004. Mineralogical and compositional changes in bones exposed on soil surfaces in Amboseli National Park, Kenya: diagenetic mechanisms and the role of sediment pore fluids. Journal of Archaeological Science 31: 721-739.

VAlera, A.C. 2010, Marfim no recinto calcolítico dos Perdigões (1): "lúnulas", fragmentação e ontologia dos artefactos. Apontamentos de Arqueologia e Património 5: 31-42.

VALERA, A.C. 2012. A "Vaca de Almada" e o problema das relações Homem/Animal na Pré-História Recente. Almadan 17: 22-29.

VAlerA, A.C. 2015.The diversity of ideotechnic objects at Perdigões enclosure: a first inventory of items and problems. Arpi 3: 238-256.

Valera, A.C. 2017. The 'Exogenous' at Perdigões Approaching Interaction in the Late 4 th and 3rd Millennium $\mathrm{BC}$ in Southwest Iberia. In: $\mathrm{M}$. Bartlheim, P. Bueno Ramírez \& M. Kunst (Eds.), Key resources and sociocultural developments in the Iberian Chalcolithic: 201-224.
VALERA, A.C. ed. 2018.Os Perdigões Neolíticos. Génese e desenvolvimento (de meados do $4^{\circ}$ aos inícios do $3^{\circ}$ milénio ac). Perdigões Monográfica 1, Lisboa, NIA-ERA.

VALERA, A.C. ed. 2019a. Fragmentation and depositions in Pre and Proto-Historic Portugal. Lisboa, NIA-Era Arqueologia.

VALERA, A.C. 2019b. Segmentation and depositional practices in Prehistoric South Portugal: between ontological stability and fluidity.In: A.C. Valera (Ed.), Fragmentation and depositions in Pre and ProtoHistoric Portugal, Lisboa, NIA-Era Arqueologia: 929.

Valera, A.C., Costa, C. 2013a. Animal limbs in funerary contexts in southern Portugal and the question of segmentation. Anthropozoologica 48 (2): 263-275.

VAlera, A.C.; Costa, C. 2013b. Uma particularidade ritual: a associação de falanges de ovinos-caprinos a falanges humanas nos sepulcros da Sobreira de Cima. In A.C. Valera (Coord.), Sobreira de Cima. Necrópole de Hipogeus do Neolítico (Vidigueira, Beja), Era Monográfica 1, NIA, Lisboa:63-70.

VALERA, A.C.; Godinho, R. 2009.A gestão da morte nos Perdigões (Reguengos de Monsaraz): novos dados, novos problemas. Estudos Arqueológicos de Oeiras 17: 371-387.

Valera, A.C.; Silva, A.M.; Cunha, C.; Evangelista, L.S. 2014a.Funerary practices and body manipulations at Neolithic and Chalcolithic Perdigões ditched enclosures (South Portugal). In: A.C. VAlera (Ed), Recent Prehistoric Enclosures and Funerary Practices, BAR International Series 2676, Oxford, Archaeopress: $37-57$.

VAlera, A.C.; Silva, A.M.; Márouez Romero, J.E. 2014b. The temporality of Perdigões enclosures: absolute chronology of the structures and social practices. SPAL 23: 11-26.

Valera, A.C.; Schuhmacher, T.X.; BanerJee, A 2015.Ivory in the Chalcolithic enclosure of Perdigões (South Portugal): the social role of an exotic raw material. World Archaeology 47:3: 390-413.

Villa, P.; MahieU, E. 1991. Breakage patterns of human long bones. Journal of Human Evolution 21: 27-48.

ZEDER, M.A. 2006. Reconciling rates of long bone fusion and tooth eruption and wear in sheep (Ovis) and goat (Capra). In: D. Ruscillo (Ed.), Recent advances in ageing and sexing animal bones. Proceedings of the 9th conference of the International Council of Archaeozoology, Durham, August 2002, Oxford, Oxbow Books:87-118.

Zeder, M.A.; LAPHAM, H.A. 2010. Assessing the reliability of criteria used to identify postcranial bones in sheep, Ovis, and goats, Capra. Journal of Archaeological Science 37(11): 2887-2905.

Zeder, M.A.; PilaAr, S.E. 2010. Assessing the reliability of criteria used to identify mandibles and mandibular teeth in sheep, Ovis, and goats, Capra. Journal of Archaeological Science 37:225-242. 